See discussions, stats, and author profiles for this publication at: https://www.researchgate.net/publication/344189628

Sedimentological and stratigraphic criteria to distinguish between basin-floor and slope mudstones: Implications for the delivery of mud to deep-water environments

Preprint $\cdot$ September 2020

DOI: $10.13140 /$ RG.2.2.31964.00643

CITATIONS

READS

0

497

6 authors, including:

Kévin Boulesteix

The University of Manchester

10 PUBlications 34 CITATIONS

SEE PROFILE

Steve Flint

The University of Manchester

175 PUBLICATIONS 5,039 CITATIONS

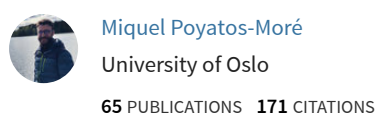

65 PUBLICATIONS 171 CITATIONS

SEE PROFILE

SEE PROFILE

Cag David Mark Hodgson

194 PUBLICATIONS 4,098 CITATIONS

SEE PROFILE

Some of the authors of this publication are also working on these related projects:

Project Early Jurassic syn- to post-rift transition in the SW Neuquén basin View project

Project The Castissent Depositional Sequences: a source-to-sink multidisciplinary project View project 
This manuscript is a preprint and has been submitted to Depositional Record. The manuscript has not undergone peer review. Subsequent versions of this manuscript may have different content. Please feel free to contact either of the authors directly to comment on the manuscript. 
Running Head: Basin-floor versus slope mudstones

\section{Title: Sedimentological and stratigraphic criteria to distinguish between basin-floor and slope mudstones: Implications for the delivery of mud to deep-water environments}

Authors: Kévin Boulesteix ${ }^{1 *}$, Miquel Poyatos-Moré ${ }^{2}$, Stephen S. Flint ${ }^{1}$, David M. Hodgson ${ }^{3}$, Kevin T. Taylor ${ }^{1}$, Rufus L. Brunt ${ }^{1}$

\section{Institutions:}

${ }^{1}$ Department of Earth and Environmental Sciences, University of Manchester, Oxford Road, Manchester M13 9PL, UK

${ }^{2}$ Department of Geosciences, University of Oslo, Oslo 0371, Norway

${ }^{3}$ School of Earth and Environment, University of Leeds, Leeds LS2 9JT, UK

*Email: kevin.boulesteix@gmail.com

Keywords: Mudstones, Basin-floor, Slope, Depositional processes, Karoo Basin 


\begin{abstract}
Deep-water mudstones overlying basin-floor and slope sandstone-prone deposits are widely interpreted as hemipelagic drapes deposited during extended periods of sand starvation. However, the processes of mud transport and deposition, and the resulting facies and sedimentary architecture of mudstones in different deep-water environments, remain poorly understood. This study documents the sedimentology and stratigraphy of basin-floor and slope mudstone units intercalated with sandstone-prone deposits of the Laingsburg depocentre (Karoo Basin, South Africa). The mudstone units have been mapped for $2500 \mathrm{~km}^{2}$ and investigated using macroscopic and microscopic descriptions from a continuous core dataset. Basin-floor mudstones exhibit a repeated and predictable alternation of bedsets dominated by low-density turbidites, and massive packages dominated by debrites, with evidence of turbulent to laminar flow transformations. Slope mudstones exhibit a similar facies assemblage, but the proportion of low-density turbidites is higher, bioturbation is more pervasive, and no repeated or predictable facies organisation is recognised. Regional mapping evidences a gradual basinward tapering of all mudstone units, consistent with the distal part of basin margin clinothems, and suggests a dominant line-source of mud delivery beyond the shelf edge. However, the well-ordered and predictable facies organisation of the basin-floor mudstones also suggest the presence of local point sources from active slope conduits, responsible for the deposition of compensationally-stacked muddy lobes. The lack of a predictable facies organisation in slope mudstones suggests deposition took place in a more variable range of subenvironments. For the first time we present a set of sedimentological and stratigraphic criteria to distinguish between submarine slope and basin-floor mudstones, which may provide an important tool to refine palaeogeographic reconstructions of other deep-water successions. This study suggests that deep-water mud can be delivered dominantly by sediment gravity flows through both line- and pointsource supply, during periods of up-dip sand storage, challenging the model of basin-floor sediment starvation.
\end{abstract}




\section{INTRODUCTION}

The nature of the sediment supplied from shelf to deep-water environments is controlled by a complex interplay between accommodation, basin margin physiography and process regime, tectonics, and climate (e.g., Hadler-Jacobsen et al., 2005; Carvajal and Steel, 2009; Dixon et al., 2012; Bourget et al., 2014; Gong et al., 2016; Laugier and Plink-Björklund, 2016; Cosgrove et al., 2018; Paumard et al., 2020). Sand is preferentially delivered to deep-water environments when fluvio-deltaic systems are near to (or at) the shelf edge (e.g., Steel et al., 2003), when the shelf is exposed and incised (e.g., Suter et al., 1987; Porębski and Steel, 2003; Johannessen and Steel, 2005), and/or through shelf-incised canyons that capture longshore drift sediments (e.g., Covault et al., 2007). Sand can be delivered beyond the shelf edge through long-lived fixed submarine canyons (point source), or relatively uniformly over the shelf margin through multiple short-lived slope conduits or sheet-like flows (Gorsline, 1978; Reading and Richards, 1994) (line source). In the absence of significant sand transfer beyond the shelf edge, commonly during times of high shelf accommodation, the coeval deep-water deposits are fine grained, and interpreted as low-energy hemipelagic drapes (e.g., Posamentier and Kolla, 2003; Posamentier and Walker, 2006; Flint et al., 2011). Mud and mudstones are ubiquitous along basin margin successions, and tend to form laterally extensive units (e.g., Wynn et al., 2000; Gervais et al., 2006; Pyles, 2008; Van der Merwe et al., 2010; Sylvester et al., 2012; Sweet et al., 2019). Typically, these deposits are overlooked relative to their sandstone-prone counterparts, due to their fine-grained nature, and referred to as "background" deposits.

Several studies have documented the transport and deposition of mud in ancient shelf environments (e.g., Macquaker and Gawthorpe, 1993; Schieber, 1994; Macquaker et al., 2007; Plint, 2014; PoyatosMoré et al., 2016). Monitoring of modern shelf settings showed that large amounts of mud can be transported to the shelf edge and canyon heads by wave, storm or river activity, before being transferred downslope by sediment gravity flows (e.g., Walsh and Nittrouer, 1999; Puig et al., 2003; Palanques et al., 2006; Bourrin et al., 2015). These observations suggest that the transfer of mud from shelf to deepwater environments might be more energetic than previously envisaged. A few studies have also recognised a wide range of processes recorded in deep-water mudstones (low-density turbidity currents, 
debris flows, transitional flows, bottom currents, hemipelagic settling) (e.g., Schieber, 1999; Loucks and Ruppel, 2007; Trabucho-Alexandre et al., 2012; Könitzer et al., 2014; Newport et al., 2018; Boulesteix et al., 2019, 2020; Emmings et al., 2020). However, these studies tend to focus on either slope or basin-floor deposits using one-dimensional datasets, and in general lack a well-constrained three-dimensional stratigraphic framework. No previous studies have sought to compare muddominated slope and basin-floor deposits in the same succession, and therefore investigated the differences in depositional processes and stacking pattern between slope and basin-floor mudstones.

In this study, we aim to document the sedimentology and stratigraphy of several deep-water mudstone units, intercalated with sandstone-prone deposits, which encompass the basin-floor to slope transition, in the Laingsburg depocentre (Karoo Basin, South Africa). Through detailed descriptions of a continuous core dataset, within the three-dimensional stratigraphic control established by previous studies, our specific objectives are: i) to understand the range of processes transporting and depositing mud in slope and basin-floor environments; ii) to provide sedimentological and stratigraphic criteria to differentiate basin-floor from slope mudstones; and iii) to discuss the implications for the delivery and transport of mud to deep-water environments.

\section{GEOLOGICAL SETTING}

The Karoo Basin (South Africa) has been interpreted as a retroarc foreland basin that formed during the Carboniferous and Permian on the southern margin of Gondwana, with subsidence controlled by flexural loading linked to the development of a magmatic arc and associated fold-thrust belt (Cape Fold Belt) (De Wit and Ransome, 1992; Veevers et al., 1994; Visser and Prackelt, 1996; Catuneanu et al., 1998). Subsidence during the Permian was associated with dynamic topography (mantle flow), with a later transition to a retroarc foreland basin stage during the Triassic (Pysklywec and Mitrovica, 1999; Tankard et al., 2009; Blewett and Phillips, 2016).

The Laingsburg depocentre, situated in the southwestern corner of the Karoo Basin, is bounded to the south by the Swartberg Branch of the Cape Fold Belt (Figure 1A, B). The sedimentary fill comprises the Late Carboniferous to Early Jurassic Karoo Supergroup, subdivided into the glacial deposits of the 
Dwyka Group (Late Carboniferous to Early Permian), the post-glacial clastic marine Ecca Group (Permian), and the continental Beaufort Group (Permian to Triassic) (Figure 1C) (Smith, 1990; Johnson et al., 1996). The Lower Ecca Group (350 m-thick) comprises the Prince Albert, Whitehill, and Collingham formations, deposited in a sand-starved basin-floor environment (Figure 1C) (Visser, 1992; Viljoen, 1994; Chukwuma and Bordy, 2016). The overlying Upper Ecca Group (1800 m-thick) comprises: i) distal basin-floor deposits of the Vischkuil Formation (Van der Merwe et al., 2009, 2010); ii) basin-floor fans to base-of-slope deposits of the Laingsburg Formation (Units A, A/B, B) (Sixsmith et al., 2004); iii) submarine slope channel-levee complexes and incised slope valley deposits of the Fort Brown Formation (Units B/C, C, D, D/E, E, F, G) (Hodgson et al., 2011; Di Celma et al., 2011); and iv) shelf-edge and shelf deposits of the Waterford Formation (Jones et al., 2015; Poyatos-Moré et al., 2016) (Figure 1C, D).

\section{Laingsburg and Fort Brown formations}

The architecture and depositional environments of the Laingsburg and Fort Brown formations are constrained by a robust three-dimensional stratigraphic framework, established through extensive mapping over $2500 \mathrm{~km}^{2}$ (Figure 1B, D) (Grecula et al., 2003a, 2003b; Sixsmith et al., 2004; Van der Merwe et al., 2009, 2010, 2014; Figueiredo et al., 2010; Di Celma et al., 2011; Flint et al., 2011; Hodgson et al., 2011; Brunt et al., 2013a, 2013b; Morris et al., 2014a, 2014b, 2016; Spychala et al., 2015, 2017; Brooks et al., 2018a; Poyatos-Moré et al., 2019). Palaeoflow was dominantly to the northeast and east, and the main sediment entry point was located to the southwest (Van der Merwe et al., 2014). The coeval shelf deposits of the Laingsburg and Fort Brown formations are absent because of later uplift and erosion of the Cape Fold Belt. The stratigraphic framework of the Laingsburg (Units $\mathrm{A}, \mathrm{A} / \mathrm{B}, \mathrm{B}$ ) and Fort Brown (Units B/C, C, D, D/E, E, F, G) formations is based upon the recognition and mapping of continuously exposed regional mudstone units intercalated between sandstone-prone units. Mudstone units drape the underlying depositional topography, and thin gradually basinward (to the east) forming a wedge-shape geometry (Figure 1D) (Brunt et al., 2013b; Brooks et al., 2018a; Poyatos-Moré et al., 2019). The relative thicknesses of the mudstone units have been used as a tool to propose a hierarchical subdivision of the deep-water succession (Flint et al., 2011). 
In a sequence stratigraphic framework, the Laingsburg and Fort Brown formations have been subdivided into four composite sequence sets, the first comprising Unit A, the second Units $A / B$ and $B$, the third Units B/C, C and D, and the fourth Units D/E, E and F (Flint et al., 2011). Each of these composite sequence sets can be subdivided into composite sequences, which can be further subdivided into sequences, where the sandstone-prone units have been interpreted as lowstand systems tracts, and the regional mudstone units as combined transgressive and highstand systems tracts (Flint et al., 2011). Here, we focus on the sedimentology and stratigraphy of regional mudstone units deposited in basinfloor to base-of-slope (Vischkuil/A mudstone, A5/A6 mudstone, and A/B mudstone), lower slope (B/C mudstone) and mid slope (C2/C3 mudstone and C/D mudstone) environments (Figure 1C).

\section{MATERIALS AND METHODS}

This study focuses on two continuous cores from research boreholes (BAV 1A and BAV 1B) drilled in the SW corner of the Laingsburg depocentre (Baviaans area) that intersected the Vischkuil, Laingsburg, and Fort Brown formations (cumulative thickness of $796 \mathrm{~m}$ ) (Figure 1). The six regional deep-water mudstone units investigated in this study (Figure 1C) were continuously logged (cumulative thickness of $164 \mathrm{~m}$ ) graphically through dry and wet observations of well-polished core surfaces using variable lighting, and following the guidelines of Lazar et al. (2015). Logging focused on the description of macroscopically visible features including: (i) lithology, (ii) colour, (iii) physical sedimentary structures, (iv) bed contacts, (v) bed thicknesses, (vi) deformations, (vii) trace fossils, and (viii) bioturbation index. The bioturbation index (BI) was described on a $0-6$ scale using the descriptive scheme of Taylor and Goldring (1993), where 0 corresponds to non-bioturbated sediment, and 6 corresponds to completely homogenised sediment. The presence of calcium carbonate was assessed by dropping $5 \%$ hydrochloric acid onto the core. The cores were subdivided into different mudstone and sandstone facies based on distinct lithology, primary sedimentary structures, lateral continuity of the beds, and bioturbation fabric observed at core scale. Mudstone facies were later refined by observations of microscopic features in thin sections. 
A total of 56 samples were collected from BAV 1A and BAV 1B using an adjusted uniform sampling spacing method of one sample per $4.5 \mathrm{~m}$, to include every mudstone facies and features of interest (facies contacts, trace fossils, diagenetic features). Thirty samples were selected to represent all mudstone facies described at core scale, and prepared for oriented polished thin sections $(24 \times 46 \mathrm{~mm})$ normal to the bedding orientation. Each thin section was scanned using an Epson Perfection V600 flatbed scanner at a resolution of 3200 dpi. Microscopic observations in both plane-polarised light (PPL) and cross-polarised light (CPL) were performed using a Nikon Eclipse LV100NPOL optical microscope fitted with a Nikon DS-Fi2 camera. Microscopic analysis focused on the characterisation of the millimetre-scale variability in sedimentary features (grading, bed contacts, laminations), grain size, composition, and bioturbation. Each thin section was logged at sub-millimetre scale, and photomicrographs were taken at different magnifications to record sedimentary structures, bedding, and texture. Individual beds were identified based on the recognition of bedding surfaces, marked by erosion, bioturbation horizons and/or change in lithofacies (Campbell, 1967; Lazar et al., 2015). Mudstones with more than half the grains $<10 \mu \mathrm{m}$ were classified as fine mudstone, and mudstones with more than half the grains $>10 \mu \mathrm{m}$ as coarse mudstone (McCave et al., 1995). A composition modifier (siliceous, calcareous, argillaceous, and carbonaceous) was added depending on the dominant grain type (quartz, carbonate, clay, and organic matter respectively). Stratigraphic changes in bioturbation index, burrow size, and ichnodiversity were used qualitatively to infer palaeo-seafloor physico-chemical conditions (oxygen level, sedimentation rate, frequency of flow events) (e.g., Gingras et al., 2011).

Thickness data from the $\mathrm{A} / \mathrm{B}, \mathrm{B} / \mathrm{C}$, and $\mathrm{C} / \mathrm{D}$ mudstone units, obtained by walking out exposures and logging sections across the $2500 \mathrm{~km}^{2}$ study area (Figure 1B), was compiled from previous studies (Figueiredo et al., 2010; Di Celma et al., 2011; Brunt et al., 2013b; Van der Merwe et al., 2014). These data were used to create thickness maps, by plotting the thickness values using the kriging tool within ArcGIS $^{\circledR}$ Geostatistical wizard. The thicknesses of the A/B and B/C sandstone units (Brooks et al., 2018a) have been subtracted from the $\mathrm{A} / \mathrm{B}$ and $\mathrm{B} / \mathrm{C}$ mudstone thickness maps, respectively. 


\section{FACIES ANALYSIS}

We define 12 sedimentary facies (F1-F12) based on the BAV 1A and BAV 1B core description. Three mudstone facies (F1-F3) are described in detail and interpreted below (Figures 2 to 8 ). Nine sandstoneprone facies (F4-F12) are summarised and illustrated in Table 1. These twelve facies stack to form nine facies associations (FA1-FA9), which are summarised in Table 2. The sandstone-prone facies and facies associations are based on previous works (Grecula et al., 2003a, 2003b; Van der Merwe et al., 2009, 2014; Figueiredo et al., 2010; Di Celma et al., 2011; Hodgson et al., 2011; Brunt et al., 2013a, 2013b; Morris et al., 2014a, 2014b; Spychala et al., 2015, 2017; Brooks et al., 2018a), and are used here to contextualise the three-dimensional depositional setting of the regional mudstone units described from the one-dimensional core dataset. Sedimentological logs are presented from the three basin-floor mudstone units (Figure 9), the three slope mudstone units (Figure 10), and representative core sections from basin-floor (Figure 11) and slope mudstones (Figure 12).

\section{Facies 1 (F1): Very thin-bedded mudstone}

\section{Description}

Facies 1 (F1) consists of light- to mid-grey, siliceous-argillaceous, well-bedded fine to coarse mudstone (Figure 2A, B, C). Beds are laterally continuous at core scale, and range in thickness from 0.04 to $1 \mathrm{~cm}$ (very thin bedded sensu Campbell, 1967) (Figures 2A, 11B and 12B). Different grading patterns and a diverse suite of physical sedimentary structures have been recognised at thin-section scale (Figure 4). To capture this variability, beds within the thin-sections of F1 have been subdivided into six different bed types (Bed types A - F; Figures 3 and 4).

Bed type A exhibits sharp to erosional bed bases, with rare flame and load structures (Figure 3A), and a bipartite microstratigraphy (Figure 3A and 4). The lower subdivision is normally graded, with rare laterally continuous to discontinuous planar-parallel laminations (Figures $3 \mathrm{~A}$ and 4). The upper subdivision is ungraded and mottled (Figure 3A). Rare normally graded beds are characterised by a 
more complex microstratigraphy, with a basal lenticular laminated subdivision, overlain by convolute and planar-parallel laminations, and capped by a mottled subdivision (Figure 4B).

Bed type B is inversely graded and characterised by a gradational base, and a sharp upper contact (Figure 3B). Sedimentary structures consist of laterally continuous to discontinuous planar-parallel laminations located in the upper part of the bed (Figure 3B).

Bed type $\mathrm{C}$ shows a sharp to erosional base, with rare flame and load structures (Figure 3C). This type of bed is inversely-to-normally graded, and sedimentary structures include planar-parallel laminations, usually located near the middle of the bed (Figure 3C).

Bed type D is characterised by a sharp to erosional base, with rare flame and load structures (Figure 3D). Internal bed structure consists of stacked normally graded laminae ( $<1 \mathrm{~mm}$ thick), with gradational or sharp contacts (Figures 3D and 4C). Laminations are either thinning upward or thickening upward within individual beds (Figure 4C).

Bed type $\mathrm{E}$ is characterised by a sharp and erosional base, with rare flame and load structures (Figure 3E). This type of bed displays a bipartite microstratigraphy (Figure 3E). The lower subdivision is normally graded with laterally continuous to discontinuous planar-parallel laminations (Figure 3E). The upper subdivision is ungraded and characterised by a poorly sorted muddy matrix that supports outsized very fine to fine sand grains (quartz, altered feldspars, volcanic and metamorphic rock fragments, mudstone clasts) (Figure 3E).

When a bed type within F1 could not be determined confidently due to moderate bioturbation, but the bed is laterally continuous at core scale and stratification is preserved, the bed was assigned to Bed type F (Figures 3F and 4).

Bioturbation in F1 is sparse to moderate (BI: 1-3), and usually increases upward at bed scale. Individual trace fossils are readily recognised due to lithological contrasts (Figures 11B and 12B). Ichnotaxa consist mainly of Helminthopsis and Phycosiphon, with rare Planolites, which are generally $<0.5 \mathrm{~cm}$ in diameter (Figures 11B, C and 12B). 


\section{Interpretation}

The six bed types identified (Bed types A - F) suggest F1 was deposited by a wide range of processes.

Based on normal grading and planar parallel to lenticular laminae, Bed type A is interpreted to represent deposition from waning, low-density turbidity currents (sensu Lowe, 1982). The lower normally graded subdivision with planar-parallel and lenticular laminations suggests deposition under tractional currents (Piper, 1978; Stow and Shanmugam, 1980). The upper ungraded subdivision indicates suspension fallout. Convolute laminations suggest loading into unconsolidated mud (Stow and Shanmugam, 1980).

The inversely graded Bed type B suggests deposition from waxing, low-density turbidity currents, with evidence for traction transport (Mulder and Alexander, 2001; Kneller and McCaffrey, 2003). The sharp upper bed contact and absence of overlying normally graded deposits suggest sediment bypass (e.g. Stevenson et al., 2015; Poyatos-Moré et al., 2016).

The inverse-to-normal grading motif of Bed type C suggests deposition from sustained, waxing-towaning, low-density turbidity currents (i.e. hyperpycnal flows) (Mulder and Alexander, 2001; Mulder et al., 2003).

The stacking of normally graded laminae within Bed type D suggests deposition from pulsating, lowdensity turbidity currents (Ho et al., 2018).

The bipartite organisation of Bed type E with a lower normally graded subdivision, overlain by an ungraded and poorly sorted subdivision suggests deposition from strongly stratified transitional flows (Baas et al., 2011; Kane and Pontén, 2012), or from co-genetic turbidity currents (lower subdivision) and cohesive debris flows (upper subdivision) (Haughton et al., 2003).

The absence of preserved grading and sedimentary structures in Bed type $\mathrm{F}$, and its stratigraphic association with the other bed types of F1 suggest Bed type F could have been primarily deposited by any processes responsible for the accumulation of Bed types A - D (waning, waxing-to-waning, waxing, or pulsating low-density turbidity currents), prior to biogenic reworking, overprinting preexisting grading and sedimentary structures. 


\section{Facies 2 (F2): Faintly bedded mudstone}

\section{Description}

Facies 2 (F2) consists of light- to mid-grey, siliceous-argillaceous, poorly-bedded fine to coarse mudstone (Figures 2D, E, F and 5), and it is usually stratigraphically associated with F1 (Figures 9 and 10). Beds in F2 range in thickness from 0.03 to $1 \mathrm{~cm}$ (very thin bedded sensu Campbell, 1967), but are typically $<0.5 \mathrm{~cm}$ thick (Figure 5). F2 is more bioturbated than F1 (BI: 4-5), and beds are distinctively laterally discontinuous at core scale, with poorly defined bed boundaries (Figures 2D, 5A, B, 11C and 12D). At microscopic scale, no sedimentary structures are identified (Figures 2E, 5C, D, E). Grading is usually obscured by intense bioturbation, but rare normally graded beds are preserved (Figure 5D). Individual trace fossils are readily recognised due to grain-size contrasts between burrow-fill and host bed, and burrows are usually larger than in F1 ( $<2 \mathrm{~cm}$ in diameter) (Figure 5). Ichnotaxa consist mainly of Helminthopsis and Phycosiphon, with rare Chondrites, Nereites and Planolites (Figures 11C, D and 12D).

\section{Interpretation}

Remnant bedding suggests F2 was deposited by sediment gravity flows. Rare preserved normally graded beds suggest deposition from dominantly waning, low-density turbidity currents (sensu Lowe, 1982). Based on the stratigraphic association of F2 with F1, intensely bioturbated beds of F2 may have been primarily deposited by low-density turbidity currents, prior to biogenic reworking. The higher bioturbation intensity, higher ichnodiversity, and larger burrows in F2 suggest lower physicochemically stressed conditions for organisms compared to F1, potentially linked to lower sedimentation rates and longer depositional breaks (e.g., Wetzel, 1984; Heard and Pickering, 2008; Gingras et al., 2011). 


\section{Facies 3 (F3): Massive mudstone}

\section{Description}

Facies 3 (F3) consists of mid- to dark-grey, argillaceous-siliceous, fine to coarse mudstone (Figure 2G, H, I). In comparison to F1 and F2, F3 is characterised by a massive texture at core scale (Figures 2G, 11C, D, E and 12C). At microscopic scale, F3 exhibits a "starry-night" texture (e.g., Haughton et al., 2003), which consists of outsized very fine to medium sand particles supported by a poorly sorted matrix of fine to coarse mud (Figures $2 \mathrm{H}, \mathrm{I}, 6,7$ and 8). Outsized particles consist of sub-rounded to subangular individual crystals (quartz, feldspars) and composite particles (volcanic and metamorphic rock fragments, mudstone clasts) (Figures 7 and 8). Mudstone clasts are recognised based on sharp edges, differential compaction around them, and/or different internal grain orientation, and are characterised by the same composition as the surrounding matrix (Figure 8). Rarely, F3 exhibits microdeformations, marked by circular and arcuate grain alignment (Figure 8E, F). Some mudstone clasts also exhibit plastic deformations (Figure 8D, E). Rare bedding contacts are identified in thin sections, and beds are less than $2 \mathrm{~cm}$ thick, strongly bioturbated, and ungraded (Figure 6A). Bioturbation is intense to complete (BI: 5-6), and individual trace fossils are usually hard to identify due to the lack of lithological contrasts (Figure 2G). However, observations of wet core surfaces allowed us to identify a relatively diverse trace fossil assemblage that consists of Chondrites, Helminthopsis, Nereites, Phycosiphon and Planolites, which are generally $<2 \mathrm{~cm}$ in diameter (Figure 11D, E).

\section{Interpretation}

The outsized very fine to medium sand-sized particles supported by a poorly sorted mud matrix suggests F3 was deposited from either: 1) suspension fallout through the water column as dropstones of glacial (ice-rafted debris) or non-glacial origins (e.g., gastroliths, vegetation rafting, aeolian transport) (Bennett et al., 1996); or 2) low-strength, cohesive debris flows, in which sand-sized particles were not vertically segregated from mud particles during deposition (Talling et al., 2012). The rare preserved bed contacts, the poorly sorted mud matrix, and the microdeformations support the interpretation of F3 as low- 
strength, cohesive debris flow deposits (i.e. debrites), which were subsequently biogenically reworked. The similar composition of the mudstone clasts and the mud matrix suggests clasts are derived from up-dip erosion of partially consolidated seafloor mud (e.g., Haughton et al., 2003; Talling et al., 2004; Schieber et al., 2010; Patacci et al., 2014; Fonnesu et al., 2016; Boulesteix et al., 2019). Some of the mudstone clasts are relatively well rounded (Figure 8A, B), which suggest progressive disintegration and abrasion in sediment gravity flows with a component of turbulence (e.g., Haughton et al., 2003; Fonnesu et al., 2015; Boulesteix et al., 2019). Therefore, we propose that some of the massive mudstones (F3) may represent the distal expression of flows that underwent transformation from turbulent to laminar along their flow path (e.g., Baas et al., 2011; Kane et al., 2017; Baker and Baas, 2020). The intense to complete bioturbation of F3 suggests deposition under lower sedimentation rate compared to F1 and F2, associated with a relatively low frequency of flow events (e.g., Wetzel, 1984; Heard and Pickering, 2008; Gingras et al., 2011).

\section{STACKING PATTERNS AND DEPOSITIONAL ARCHITECTURE}

The description of the facies and facies associations (Tables 1 and 2) provides the sedimentological framework to describe the stacking patterns of the six mudstone units analysed (Figures 9 and 10). The stratigraphic distribution of the facies and the bed types of F1 are summarised in Figure 13. The thickness maps of the A/B, B/C, and C/D mudstone units are presented in Figure 14.

\section{Basin-floor mudstones}

The Vischkuil Formation is dominated by debrites and turbidites accumulated in a distal basin-floor environment (Van der Merwe et al., 2009, 2010), and the overlying Units A and A/B of the Laingsburg Formation are dominated by basin-floor fan to base-of-slope deposits (Grecula et al., 2003a; Sixsmith et al., 2004; Prélat and Hodgson, 2013; Brooks et al., 2018a). This suggests that the intercalated Vischkuil/A (Figure 9B), A5/A6 (Figure 9C), and A/B (Figure 9D) mudstone units were deposited in a similar basin-floor to base-of-slope environment. 
The basin-floor mudstone units (Vischkuil/A, A5/A6, A/B) are dominantly composed of massive mudstone $(\mathrm{F} 3 ; 45 \%)$ and very thin-bedded mudstone $(\mathrm{F} 1 ; 31 \%)$, associated with minor faintly bedded mudstone $(\mathrm{F} 2 ; 13 \%)$, interbedded sandstone and mudstone $(\mathrm{F} 7 ; 5 \%)$, ash-rich sandstone $(\mathrm{F} 12 ; 3 \%)$, structured sandstone (F5; 2\%) and hybrid-event bed (F8; 1\%) (Figure 13; Table 1). Within the analysed thin sections of F1 in the basin-floor mudstones (see locations in Figure 9), the most common bed type identified is graded laminated (Bed type D; 39\%), followed by normally graded (Bed type A; 26\%), bioturbated (Bed type F; 24\%), inversely-to-normally graded (Bed type C; 7.6\%), bipartite (Bed type E; 3\%), and inversely graded (Bed type B; 0.4\%) (Figure 13).

In the core dataset, the basin-floor mudstones consist of a repeated and predictable alternation of bedsets (sensu Campbell, 1967) composed of F1, F2, and F7 (FA7; Table 2) and massive packages dominated by F3 (FA9; Table 2), which occur at two scales (Figures 9 and 11A). At the smallest scale (0.01-2 m), basin-floor mudstone bedsets (FA7) are $0.01-1.70 \mathrm{~m}$ thick, and are vertically separated by relatively thin ( $<0.5 \mathrm{~m}$ thick) massive packages (FA9) occasionally associated with ash-rich sandstones (F12), pyrite nodules, and isolated beds of F1, F2 and F7. Contacts between the bedsets (FA7) and the massive packages (FA9) are commonly sharp and bioturbated (Figure 11C). Successive mudstone bedsets (FA7) separated by thin massive packages (FA9; $<0.5 \mathrm{~m}$ thick) can together fine- and thin-upward, coarsenand thicken-upward, coarsen- and thicken-upward followed by fine- and thin-upward, or can be characterised by a more disorganised stacking pattern (Figures 9 and 11A). At a larger scale $(2-5 \mathrm{~m})$, one or more mudstone bedsets (FA7), individually separated by relatively thin massive packages (FA9; $<0.5 \mathrm{~m}$ thick), form bedset packages. These bedset packages are separated by thicker massive packages (FA9; >0.5 m thick), more commonly associated with ash-rich sandstone (F12) and pyrite nodules (Figures 9 and 11A). Facies proportions, nature of contact with bounding sandstone-prone units, and noticeable features are summarised below for the three basin-floor mudstone units.

\section{Vischkuil/A mudstone}

The Vischkuil/A mudstone (7.3 m thick in BAV 1B) sharply overlies remobilised, mass-transport deposits (FA8; Table 2) of the Vischkuil Formation, and is sharply overlain by lobe axis deposits (FA1) 
of Unit A of the Laingsburg Formation (Figure 9B). This mudstone unit exhibits soft-sediment deformation and is dominated by F1 (38\%) and F3 (29\%), associated with F7 (13\%), F2 (9\%), F12 (6\%) and F5 (5\%) (Figures 9B and 13). The unit is also characterised by intercalated lobe fringe deposits (FA1) $<50 \mathrm{~cm}$ thick (Figure 9B).

\section{A5/A6 mudstone}

The A5/A6 mudstone (12.15 m thick in BAV 1B) sharply overlies lobe distal fringe deposits (FA2; Table 2) of Sub-unit A5 (after Sixsmith et al., 2004), and is sharply overlain by lobe fringe deposits (FA1) of Sub-unit A6 (Figure 9C). This mudstone unit is dominated by F3 (68\%), associated with minor F1 (14\%), F2 (14\%), F7 (1\%), F5 (1\%), F8 (1\%), and F12 (1\%) (Figures 9C and 13). This unit is characterised by the highest concentration of pyrite nodules in the succession (Figure 9C).

\section{A/B mudstone}

The A/B mudstone (39.7 m thick in BAV 1B) sharply overlies lobe distal fringe deposits (FA2; Table 2) of Unit A, and it is sharply overlain by lobe off-axis deposits (FA1) of Unit B (Figure 9D). This unit is dominated by F1 (42\%) and F3 (40\%), with minor associated F2 (16\%), F12 (1\%) and F7 (1\%) (Figures 9D and 13). The A/B mudstone is also characterised by more common carbonate-rich concretions compared to the Vischkuil/A and A5/A6 mudstone units (Figure 9). A 5.10 m-thick sandstone-prone package is intercalated in the succession (Unit $\mathrm{A} / \mathrm{B}$ ), with sharp bounding contacts, and is interpreted as disconnected basin-floor lobe deposits (Brooks et al., 2018a). The size and the concentration of outsized sand particles observed in thin sections of F3 deposits increases above Unit $\mathrm{A} / \mathrm{B}$. The $\mathrm{A} / \mathrm{B}$ mudstone unit shows a relatively constant basinward thinning toward the east-northeast (i.e. 50-5 m), associated with a wedge-shape geometry (Figure 14B).

\section{Slope mudstones}

Unit B of the Laingsburg Formation consists of weakly confined channel complexes and extensive levees (to the west), interpreted as a base-of-slope succession, and mapped $25 \mathrm{~km}$ basinward (to the east) into basin-floor lobe complexes (Brunt et al., 2013b). Therefore, the overlying B/C mudstone is 
interpreted as a lower slope succession. It also contains a thin sandstone-prone package (Unit B/C), interpreted by Brooks et al. (2018a) as an intraslope lobe, deposited on a topographic step. However, this package is not encountered in our subsurface dataset because of erosional removal by Unit $\mathrm{C}$ (Figure 10A). Unit C comprises channel-levee complexes (Hodgson et al., 2011; Morris et al., 2016) typical of a slope setting, and has been mapped for $80 \mathrm{~km}$ down depositional dip into basin-floor lobe complexes (Di Celma et al., 2011; Van der Merwe et al., 2014). Unit D includes deeply incised slope valley-fills, indicative of a mid-slope setting (Hodgson et al., 2011; Morris et al., 2016), and with basinfloor fan complex developed 70-100 km down depositional dip (Van der Merwe et al., 2014). This well constrained palaeogeographic and stratigraphic context allows for confident interpretation of the $\mathrm{C} 2 / \mathrm{C} 3$ and C/D mudstone units as mid slope deposits.

The most dominant facies in the slope mudstone units $(\mathrm{B} / \mathrm{C}, \mathrm{C} 2 / \mathrm{C} 3, \mathrm{C} / \mathrm{D})$ are faintly bedded mudstone $(\mathrm{F} 2 ; 43 \%)$ and very thin-bedded mudstone $(\mathrm{F} 1 ; 36 \%)$, associated with minor massive mudstones (F3; $18 \%$ ), interbedded sandstone and mudstone (F7; 1\%), folded deposits (F11; 1\%), and ash-rich sandstones (F12; 1\%) (Figures 10 and 13; Table 1). The most common bed type identified within the thin sections of F1 in slope mudstones (see locations in Figure 10) is bioturbated (Bed type F; 52\%), followed by normally graded (Bed type A; 33\%), graded laminated (Bed type D; 7\%), inversely-tonormally graded (Bed type C; 5\%), inversely graded (Bed type B; 3\%) (Figure 13). Bipartite beds (Bed type E) have not been observed in the thin-section dataset.

Similar to basin-floor deposits, slope mudstones consist of a repeated alternation of bedsets composed of F1, F2 and F7 (FA8; Table 2) and massive packages dominated by F3 (FA9; Table 2) (Figures 10 and 12A). However, the distinctive and predictable two-scale organisation recognised for the basinfloor mudstones (i.e. bedsets and bedset packages) is not observed in the slope deposits. Slope bedsets (FA8) are usually thicker (0.01-8 m thick), more bioturbated, and more commonly associated with carbonate-rich concretions when compared to basin-floor bedsets (Figures 10 and 12A). The massive mudstone packages (FA9) are 0.02-1.4 m thick, with less common pyrite nodules compared to the basinfloor deposits (Figures 10 and 12). Facies proportions, nature of contacts with bounding sandstoneprone units, and noticeable features are summarised below for the three slope mudstone units. 


\section{B/C mudstone}

The B/C mudstone (49.3 m thick in BAV 1A) gradationally overlies Unit B external levee deposits (FA5; Table 2), and is truncated by slope valley-fill deposits (FA4) of Unit C (Figure 10A). This unit is dominated by F2 (56\%) and F3 (27\%), associated with minor F1 (15\%), F12 (1\%) and F11 (1\%) (Figures $10 \mathrm{~A}$ and 13). The $\mathrm{B} / \mathrm{C}$ mudstone unit displays a thinning pattern towards the north, northeast and east (i.e. 65-5 m), associated with a more radial wedge-shape geometry (Figure 14C).

\section{C2/C3 mudstone}

The $\mathrm{C} 2 / \mathrm{C} 3$ mudstone (7.7 $\mathrm{m}$ thick in BAV 1A) gradationally overlies external levee deposits (FA5; Table 2) of Sub-unit C2, and is gradationally overlain by intraslope frontal lobe deposits (FA7) of Subunit C3 (Morris et al., 2014b, 2016; Figure 10B). This unit is dominated by F2 (58\%) and F1 (31\%), associated with minor F3 (7\%), F7 (3\%) and F12 (1\%) (Figures 10B and 13).

\section{C/D mudstone}

The C/D mudstone (22.6 m thick in BAV 1A) sharply overlies intraslope frontal lobe deposits (FA7; Table 2) of Sub-Unit C3, and it is sharply overlain by external levee deposits (FA5) of Unit D (Kane and Hodgson, 2011; Figure 10C). This unit is dominated by F1 (62\%), with minor associated F3 (19\%), F2 (17\%), F7 (1\%) and F12 (1\%) (Figures 10C and 13). The C/D mudstone unit exhibits a relatively constant basinward thinning toward the northeast (i.e. $30-5 \mathrm{~m}$ ), associated with a wedge-shape geometry (Figure 14D).

\section{DISCUSSION}

\section{What do basin-floor and slope mudstones represent?}

The description of the one-dimensional core dataset (Figures 9 and 10) combined with regional thickness mapping (Figure 14), and the three-dimensional contextual knowledge from previous studies 
of the Laingsburg succession, allow for a palaeogeographic reconstruction of the depositional environments recorded by the deep-water regional mudstone units (Figure 15).

\section{Basin-floor mudstones}

Physical mapping across the Laingsburg depocentre has shown that the regional basin-floor mudstone units (Vischkuil/A, A5/A6, A/B) do not correlate laterally to coeval sandstones (Sixsmith et al., 2004; Brunt et al., 2013b; Van der Merwe et al., 2014). Thickness maps display a gradual basinward tapering to the northeast, associated with a wedge-shape geometry and relatively constant lateral thickness changes (Figure 14B). This regional-scale architecture suggests that deep-water mudstone units are possibly the distal part of basin margin clinothems (i.e. bottomsets), associated with a dominantly linear source of mud beyond the shelf edge (e.g., Reading and Richards, 1994; Prather et al., 2017; PoyatosMoré et al., 2019). Basin-floor deposits from linear source systems are usually characterised by slump deposits, and are poorly organised because of the uniformly distributed and random sediment input along the margin (e.g., Gorsline and Emery, 1959; Heller and Dickinson, 1985; Surlyk, 1987; Reading and Richards, 1994). However, the basin-floor mudstones from the Laingsburg depocentre in the specific borehole locality are organised in a repeated and predictable facies organisation, which occurs at two scales: 1) relatively thin massive packages dominated by debrites (FA9; $<0.5 \mathrm{~m}$ thick) separate bedsets dominated by low-density turbidites (FA7); 2) thicker massive packages (FA9; >0.5 m thick) separate a group of bedsets to form bedset packages (Figures 9 and 11; Table 2). The well-ordered and repeated nature of the succession in the one-dimensional core dataset suggests that, in addition to a linear source of mud responsible for the wedge shape geometry of the units, additional styles of feeder systems may have delivered fine-grained sediment to the basin-floor.

The coeval up-dip shelf and slope deposits of the basin-floor mudstone units to the west and southwest of the study area are not exposed due to later uplift and erosion; therefore, the physiography of the sediment feeder systems is unknown. However, Units A and B of the Laingsburg Formation consist of base-of-slope to basin-floor sand-prone lobes, interpreted to be point-sourced from a long-term fixed slope canyon system directly up depositional dip to the west-southwest of the study area (Grecula et al., 
2003a; Brunt et al., 2013b). Previous works have also suggested that local seafloor topography was created on the basin-floor to base-of-slope during the accumulation of the mudstone units (Brooks et al., 2018a). Thus, the inferred presence of seafloor topography and long-term slope conduits directly up depositional dip of the study area suggest that mud, in the specific borehole locality, may have also been sourced from: i) flows stripped from intraslope or basin-floor confinement to build spillover fringes on the basin-floor (e.g., Sinclair and Tomasso, 2002; Brooks et al., 2018b), with some potential sand trapped up depositional dip (intraslope lobes; e.g., Plink-Björklund and Steel, 2002; Spychala et al., 2015); and/or ii) flows delivered through partially filled submarine slope conduits to build basinfloor mudstone lobes. Spillover fringe deposits originate from the uppermost dilute part of flows breaching up-dip topography (e.g., Sinclair and Tomasso, 2002), and therefore, only waning, lowdensity turbidity currents are expected to be deposited in the down-dip environments (e.g., Brooks et al., 2018b). However, microscopic observations suggest the basin-floor mudstone bedsets (FA7) accumulated from a wide range of sediment gravity flows (Figures 3 and 13), with evidence of flow fluctuations (Bed type D; Figure 3D). Also, the low to intense bioturbation (BI: 1-5), relatively small burrows, and low ichnodiversity of the basin-floor mudstone bedsets (FA7) point towards variably stressed seafloor conditions, potentially linked to periods of more frequent and efficient sediment gravity flows reaching the basin-floor (e.g., Wetzel, 1984; Heard and Pickering, 2008). The variable vertical stacking pattern of successive bedsets (FA7; Figure 9) separated by thin massive mudstones (FA9; <0.5 m thick) may also suggest compensational stacking (e.g., Prélat et al., 2009; Prélat and Hodgson, 2013; Boulesteix et al., 2020). The well-ordered and potentially compensational nature, the sedimentological evidence for flow fluctuations, and the ichnological evidence for frequent sediment delivery to the basin-floor, support an interpretation of the mudstone bedsets (FA7) as basin-floor mudstone lobes (Figure 15), supplied via underfilled slope canyons. The higher bioturbation intensity (BI: 5-6), higher ichnodiversity, and larger burrows associated with the massive mudstone packages (FA9) suggest more favourable physico-chemical conditions for burrowing organisms, linked to more infrequent debris flows reaching the basin-floor (e.g., Wetzel, 1984; Heard and Pickering, 2008). The debrite-rich packages (FA9) are therefore interpreted as accumulated outside the mudstone lobes, potentially linked to autogenic compensational stacking and/or allogenically-controlled backstepping 
of the sediment delivery system (e.g., Boulesteix et al., 2019, 2020). The relatively thick massive mudstone packages (FA9; >0.5 m thick) are more commonly associated with ash-rich sandstones (F12; Table 1), which suggests longer-term decrease of sedimentation rate to the basin-floor.

The relatively high proportion of debrites on the basin-floor mudstones of the deep-water Laingsburg succession is consistent with a distal position, more prone to flow transformations from turbulent to laminar (e.g., Haughton et al., 2003; Talling et al., 2004; Hodgson, 2009; Kane et al., 2017; Baker and Baas, 2020). The high mud content on the seafloor during the interpreted relative sea-level highstand periods in the Karoo Basin (Flint et al., 2011) and its incorporation in sediment gravity-flows may have favoured flow transformations by enhancing the damping of flow turbulence (Baas and Best, 2002; Baas et al., 2011). Deep-water massive mudstones are commonly interpreted as hemipelagites based on their homogeneous texture in cores and outcrops. However, our study along with other recent studies of deep-water mudstones (e.g., Könitzer et al., 2014; Newport et al., 2018; Boulesteix et al., 2019, 2020; Emmings et al., 2020) indicate that massive-looking mudstones at macroscopic scale may contain microscopic outsized particles, which suggest they are often deposited by much higher energy processes than previously assumed.

\section{Slope mudstones}

Similar to the basin-floor deposits, the slope mudstone units (B/C, C2/C3, C/D) do not correlate laterally to any coeval sandstones, and show a wedge-shape geometry (Figure 14C, D). This suggests they also form part of basin margin clinothems (i.e. foresets), associated with a dominant linear source of mud beyond the shelf edge (e.g., Reading and Richards, 1994; Prather et al., 2017; Poyatos-Moré et al., 2019). However, in contrast to the basin-floor mudstones, the slope deposits show: i) a higher proportion of low-density turbidites (FA8; Table 2) compared to debrites (FA9; Table 2); ii) a less predictable stacking pattern; iii) more common carbonate-rich concretions and carbonate-cemented burrows; iv) higher bioturbation intensity; and v) larger burrows (Figures 10 and 12). Units C and D of the Fort Brown Formation consist of a channelised submarine slope succession in the Baviaans area (Hodgson et al., 2011; Di Celma et al., 2011; Morris et al., 2016), with evidence for a stepped profile (Van der 
Merwe et al., 2014; Brooks et al., 2018 a). The composite erosion surface of Unit D remained underfilled during the abandonment phase (Hodgson et al., 2011), which suggests slope conduits may have remained partially open and active during the accumulation of the intercalated regional mudstone units. Seafloor topography was generated on the slope during the accumulation of mudstones, creating an "out of grade" slope profile which may have influence sediment gravity flows (Brooks et al., 2018a). Slope mudstone bedsets (FA8; Table 2) may therefore locally represent spillover fringe deposits (Figure 15) (e.g., Sinclair and Tomasso, 2002; Brooks et al., 2018b), with some sand-prone parts of flows trapped up depositional dip to form intraslope lobes (e.g., Plink-Björklund and Steel, 2002; Spychala et al., 2015). However, slope bedsests (FA8) may also be derived from flows escaping lateral confinement from slope conduits to build external levees (Figure 15) (e.g., Buffington, 1952; Normark et al., 1980; Beaubouef, 2004; Morris et al., 2014a). The aggradational stacking of FA8 deposits, with packages up to $8 \mathrm{~m}$ thick (Figures 10 and 12), may be also explained by local flow confinement in slope accommodation (e.g., Ferry et al., 2005; Spychala et al., 2015, 2017). Thus, the less predictable stacking pattern of the slope mudstones in the one-dimensional core dataset (Figure 10), combined with the three-dimensional palaeogeographic control from previous studies, suggest mud may have accumulated by a combination of processes on a topographically complex slope, and in a wider range of depositional sub-environments than basin-floor mudstones (Figure 15).

The higher relative proportion of low-density turbidites (FA8) in the slope mudstones compared to the basin-floor mudstones (FA7) may be explained by the more proximal position relative to the sediment source, with more frequent low-density turbidity currents reaching this part of the margin profile. The higher bioturbation intensity and larger burrows of FA8 deposits compared to FA7 may be consistent with the relatively shallower depositional environment, which may have favoured higher seafloor oxygenation (e.g., Wetzel and Uchman, 2001; Heard and Pickering, 2008; Heard et al., 2014). The strong bioturbation of the intercalated massive mudstone packages (FA9; Table 2) suggests they accumulated from more infrequent debris flows (e.g., Wetzel, 1984; Heard and Pickering, 2008), and are interpreted to represent periods of reduced sediment input, potentially linked to allogenic and/or autogenic backstepping or avulsion of the sediment delivery system (e.g., Boulesteix et al., 2019). 


\section{Implications for the delivery of mud to deep-water environments}

The Laingsburg deep-water succession exhibits an organised alternation of sandstone- and mudstoneprone units (Figure 1C). This stratigraphic motif has been commonly observed in other deep-water successions in outcrops (e.g., Mutti and Normark, 1987; Gardner et al., 2003; Hodgson et al., 2006; Pyles, 2008; Grundvåg et al., 2014; Pickering and Cantalejo, 2015; Terlaky et al., 2016), and in subsurface datasets (e.g., Beaubouef and Friedmann, 2000; Wynn et al., 2000; Gervais et al., 2006; Sylvester et al., 2012; Prather et al., 2017; Sweet et al., 2019). In the Laingsburg depocentre, the sandstone-prone deep-water units have been interpreted to be lowstand systems tracts, deposited during falling to low sea level stands, when deltas reached the shelf edge, or when the shelf was exposed, supplying sand directly to the heads of submarine canyon-channel systems (Flint et al., 2011). The regional mudstone units investigated in this study (Vischkuil/A, A5/A6, A/B, B/C, C2/C3, C/D) have been interpreted to be combined transgressive and highstand systems tracts, deposited during relative sea-level rise and highstand, when deltas were shelf-confined, resulting in a deactivation of slope canyon-channel systems and cessation of sand supply to deep-water environments (Flint et al., 2011). Commonly, deep-water regional mudstones are interpreted to be line sourced and dominated by hemipelagic fallout deposits, passively draping the seafloor (e.g., Posamentier and Kolla, 2003; Posamentier and Walker, 2006; Pyles, 2008; Flint et al., 2011). However, our study challenges this, and shows that: i) mud can be delivered to the slope and the basin-floor by a combination of line and point source delivery systems; and ii) deep-water mudstones can be dominated by the product of multiple sediment gravity flows including a wide range of low-density turbidity currents and low-strength cohesive debris flows (Figure 15).

Several physical processes must be considered for the relatively continuous transfer of mud to the shelf edge and the heads of shelf-incised slope conduits during the absence of the sand-dominated systems. Monitoring program of modern shelf environments have revealed that mud can be transported by energetic processes, such as hyperpycnal flows, and resuspension of mud by waves and storms, generating turbulent transport of fluid mud that migrates either along, or across the shelf (e.g., Cacchione et al., 1995; Kineke et al., 1996; Ogston et al., 2000; Traykovski et al., 2000; Wright et al., 
2001). Some of this mud may be stored on the shelf to form mud belts (e.g., Wells and Coleman 1981; Lee et al., 2001). Mud can also be efficiently advected to the shelf edge and the canyon heads, and transferred down the slope through canyon-channel systems (e.g., Walsh and Nittrouer, 1999; Puig et al., 2003; Palanques et al., 2006; Bourrin et al., 2015). The coeval shelf of the deep-water succession investigated here is now absent because of later uplift and erosion, and therefore, the sedimentary processes that were acting on the shelf up depositional dip are unknown. However, the overlying shelf succession of the Waterford Formation shows evidence for recurrent supply of mud to the shelf edge and the upper slope, mainly through the action of wave and/or storm reworking of mud previously deposited from river floods (Poyatos-Moré et al., 2016). This suggests that similar processes may have acted on the coeval shelf to the Laingsburg and Fort Brown formations, during high accommodation conditions, to efficiently transfer mud beyond the shelf edge and to the head of underfilled slope canyons. The wedge-shape geometry of the mudstone units at regional scale suggests that most of the mud was transported and deposited on the slope and proximal basin-floor environments by recurrent gravity-driven supply from a linear source (Figure 15). However, the sedimentological and stratigraphic evidence for the accumulation of point-sourced basin-floor mudstone lobes also suggest that slope conduits were not necessarily deactivated during the backstepping or avulsion of the sand-dominated part of the system, and could deliver mud to some parts of the basin-floor (Figure 15). These findings have important implications for the correct interpretation of deep-water mudstone depositional processes, and indicate that significant energetic processes can still occur in deep-water systems during periods when sand is stored on the shelf.

\section{CONCLUSIONS}

A continuous core dataset and a well-constrained three-dimensional stratigraphic and palaeogeographic context has allowed us to document the variability in depositional processes and stacking patterns between slope and basin-floor mudstones within the same basin margin succession (Laingsburg depocentre, Karoo Basin, South Africa). Typically, deep-water mudstones are interpreted as dominated by the product of hemipelagic fallout, but the mudstones from the Laingsburg depocentre are heterogeneous and dominated by sediment gravity flow deposits. In the one-dimensional core dataset, 
basin-floor mudstones exhibit a repeated and predictable alternation of bedsets and massive packages. Microscopic observations indicate bedsets consist of six bed types deposited by a wide range of lowdensity turbidity currents (waning, waxing, waxing-to-waning, multi-pulsed), and occasional transitional flows. The intercalated massive mudstones are pervasively bioturbated and contain outsized sand particles, and are interpreted as deposited by low-strength cohesive debris flows, with evidence of flow transformations from turbulent to laminar. The slope mudstones show a similar facies assemblage, but are characterised by a higher proportion of low-density turbidites compared to debrites, a less predictable facies stacking pattern, more common carbonate-rich concretions, a higher bioturbation intensity, and larger burrows. The thickness maps of the mudstone units across the $2500 \mathrm{~km}^{2}$ study area show a gradual basinward tapering and a wedge-shape geometry, consistent with the distal part of basin margin clinothems, and thus a dominant line-sourced delivery of mud beyond the shelf edge. However, the stratigraphic context and the well-ordered and repeated organisation of the basin-floor mudstones in the core locality suggest that some of the mud was locally point-sourced through underfilled slope conduits, associated with relative sea-level change and autogenic compensational stacking of basinfloor mudstone lobes. The less predictive stacking pattern of the slope mudstone suggests they likely accumulated in a wider range of depositional environments within a topographically complex slope. The development of recognition criteria to distinguish between slope and basin-floor mudstones has implications for the palaeogeographic interpretations of other deep-water mudstone successions. The wide spectrum of depositional processes and environments recognised within these deep-water mudstones suggest that mud-rich submarine canyon-channel systems can still remain as pathways to deliver recurrent sediment gravity flows to the slope and basin-floor during times when sand is sequestered on the shelf. This study shows that flow energy conditions in deep-water mud-prone environments can be significantly higher than previously assumed, and may provide insights to improve models for the transport and deposition of fine-grained particles, such as microplastics and other pollutants in the deep oceans. 


\section{ACKNOWLEDGEMENTS}

The work presented here is part of the SLOPE Project, Phase 4. We thank the consortium of sponsors (Anadarko, BHP, BP, CNOOC-Nexen, ConocoPhillips, Equinor, Maersk, Murphy, Neptune Energy, Petrobras, Premier Oil, Shell, Total, VNG Norge and Woodside) for financial support. We also thank the IAS for a postgraduate research grant. We thank De Ville Wickens for field support, and the Karoo farmers for access to their land. Rachel Healy is thanked for assistance in the core store.

\section{CONFLICT OF INTEREST}

The authors have no conflict of interest to declare.

\section{DATA AVAILABILTY STATEMENT}

The data that support the findings of this study are available from the corresponding author upon reasonable request. 


\section{REFERENCES}

Allen, J.R.L. (1982) Sedimentary Structures: Their Character and Physical Basis, Volumes 1, 2: Amsterdam, Elsevier, 593 p., 663 p.

Arnott, R.W.C. and Hand, B.M. (1989) Bedforms, primary structures and grain fabric in the presence of suspended sediment rain. Journal of Sedimentary Research, 59(6), 1062-1069.

Baas, J.H. and Best, J.L. (2002) Turbulence modulation in clay-rich sediment-laden flows and some implications for sediment deposition. Journal of Sedimentary Research, 72(3), 336-340.

Baas, J.H., Best, J.L. and Peakall, J. (2011) Depositional processes, bedform development and hybrid bed formation in rapidly decelerated cohesive (mud-sand) sediment flows. Sedimentology, 58(7), 19531987.

Baker, M.L. and Baas, J.H. (2020) Mixed sand-mud bedforms produced by transient turbulent flows in the fringe of submarine fans: Indicators of flow transformation. Sedimentology.

Beaubouef, R.T. and Friedmann, S.J. (2000) High resolution seismic/sequence stratigraphic framework for the evolution of Pleistocene intra slope basins, western Gulf of Mexico: depositional models and reservoir analogs. In: Deep-water reservoirs of the world: Gulf Coast Section SEPM 20th Annual Research Conference, pp. 40-60.

Beaubouef, R.T. (2004) Deep-water leveed-channel complexes of the Cerro Toro Formation, Upper Cretaceous, southern Chile. AAPG bulletin, 88(11), 1471-1500.

Bennett, M.R., Doyle, P., and Mather, A.E. (1996) Dropstones: their origin and significance. Palaeogeography, Palaeoclimatology, Palaeoecology, 121(3-4), 331-339.

Best, J.L and Bridge, J. (1992) The morphology and dynamics of low amplitude bedwaves upon upper stage plane beds and the preservation of planar laminae. Sedimentology, 39(5), 737-752. 
Blewett, S. and Phillips, D. (2016) An overview of Cape Fold Belt geochronology: implications for sediment provenance and the timing of orogenesis. In: Linol, B. and De Wit, M.J. (Eds) Origin and Evolution of the Cape Mountains and Karoo Basin, Springer, Cham., pp. 45-55.

Boulesteix, K., Poyatos-Moré, M., Flint, S.S., Taylor, K.G., Hodgson, D.M. and Hasiotis, S.T. (2019) Transport and deposition of mud in deep-water environments: Processes and stratigraphic implications. Sedimentology, 66(7), 2894-2925.

Boulesteix, K., Poyatos-Moré, M., Hodgson, D.M., Flint, S.S. and Taylor, K.G. (2020) Fringe or background: Characterizing deep-water mudstones beyond the basin-floor fan sandstone pinchout. Journal of Sedimentary Research.

Bourget, J., Ainsworth, R.B. and Thompson, S. (2014) Seismic stratigraphy and geomorphology of a tide or wave dominated shelf-edge delta (NW Australia): process-based classification from 3D seismic attributes and implications for the prediction of deep-water sands. Marine and Petroleum Geology, 57, 359-384.

Bourrin, F., Many, G., de Madron, X.D., Martín, J., Puig, P., Houpert, L., Testor, P., Kunesch, S., Mahiouz, K. and Béguery, L. (2015) Glider monitoring of shelf suspended particle dynamics and transport during storm and flooding conditions. Continental Shelf Research, 109, 135-149.

Brooks, H.L., Hodgson, D.M., Brunt, R.L., Peakall, J., Poyatos-Moré, M. and Flint, S.S. (2018a) Disconnected submarine lobes as a record of stepped slope evolution over multiple sea-level cycles. Geosphere, 14, 1753-1779.

Brooks, H.L., Hodgson, D.M., Brunt, R.L., Peakall, J., Hofstra, M. and Flint, S.S. (2018b) Deep-water channel-lobe transition zone dynamics: Processes and depositional architecture, an example from the Karoo Basin, South Africa. GSA Bulletin, 130(9-10), 1723-1746.

Brunt, R.L., Di Celma, C.N., Hodgson, D.M., Flint, S.S., Kavanagh, J.P. and van der Merwe, W.C. (2013a) Driving a channel through a levee when the levee is high: An outcrop example of submarine downdip entrenchment. Marine and Petroleum Geology, 41, 134-145. 
Brunt, R.L., Hodgson, D.M., Flint, S.S., Pringle, J.K., Di Celma, C., Prélat, A. and Grecula, M. (2013b) Confined to unconfined: Anatomy of a base-of-slope succession, Karoo Basin, South Africa. Marine and Petroleum Geology, 41, 206-221.

Buffington, E.C. (1952) Submarine 'natural levees'. J. Geol., 60, 473-479.

Cacchione, D.A., Drake, D.E., Kayen, R.W., Sternberg, R.W., Kineke, G.C. and Tate, G.B. (1995) Measurements in the bottom boundary layer on the Amazon subaqueous delta. Marine Geology, 125(34), 235-257.

Campbell, C.V. (1967) Lamina, laminaset, bed and bedset. Sedimentology, 8(1), 7-26.

Carvajal, C. and Steel, R. (2009) Shelf-edge architecture and bypass of sand to deep-water: Influence of shelf-edge processes, sea level, and sediment supply. Journal of Sedimentary Research, 79(9), 652672.

Catuneanu, O., Hancox, P.J. and Rubidge, B.S. (1998) Reciprocal flexural behaviour and contrasting stratigraphies: a new basin development model for the Karoo retroarc foreland system, South Africa. Basin Research, 10, 417-439.

Chukwuma, K. and Bordy, E.M. (2016) Spatiotemporal sedimentary facies variations in the Lower Permian Whitehill Formation, Ecca Group, Karoo Basin. In: Linol, B., and De Wit, M.J., (Eds) Origin and Evolution of the Cape Mountains and Karoo Basin, Springer, Cham., pp. 101-110.

Cosgrove, G.I.E., Hodgson, D.M., Poyatos-Moré, M., Mountney, N.P. and McCaffrey, W.D. (2018) Filter or Conveyor? Establishing relationships between clinoform rollover trajectory, sedimentary process regime, and grain character within intrashelf clinoform, offshore New Jersey, U.S.A. Journal of Sedimentary Research, 88, 917-941.

Covault, J.A., Normark, W.R., Romans, B.W. and Graham, S.A. (2007) Highstand fans in the California borderland: The overlooked deep-water depositional systems. Geology, 35(9), 783-786. 
De Wit, M.J. and Ransome, I.G.D. (1992) Regional inversion tectonics along the southern margin of Gondwana. In: De Wit, M.J. and Ransome, I.G.D. (Eds) Inversion tectonics of the Cape Fold Belt, Karoo and Cretaceous Basins of Southern Africa, A.A. Balkema, Rotterdam, pp. 15-21.

Di Celma, C., Brunt, R.L., Hodgson, D.M., Flint, S.S. and Kavanagh, J.P. (2011) Spatial and temporal evolution of a Permian submarine slope channel-levee system, Karoo Basin, South Africa. Journal of Sedimentary Research, 81, 579-599.

Dixon, J.F., Steel, R.J. and Olariu, C. (2012) River-dominated, shelf-edge deltas: delivery of sand across the shelf break in the absence of slope incision. Sedimentology, 59, 1133-1157.

Emmings, J.F., Davies, S.J., Vane, C.H., Moss-Hayes, V. and Stephenson, M.H. (2020) From marine bands to hybrid flows: Sedimentology of a Mississippian black shale. Sedimentology, 67(1), 261-304.

Ferry, J.N., Mulder, T., Parize, O. and Raillard, S. (2005) Concept of equilibrium profile in deep-water turbidite system: effects of local physiographic changes on the nature of sedimentary process and the geometries of deposits. In: Hodgson, D.M. and Flint, S.S. (Eds), Geological Society, London, Special Publications, 244(1), pp. 181-193.

Figueiredo, J.J.P., Hodgson, D.M. and Flint, S.S. (2010) Depositional environments and sequence stratigraphy of an exhumed Permian mud-dominated submarine slope succession, Karoo basin, South Africa. Journal of Sedimentary Research, 80, 97-118.

Flint, S.S., Hodgson, D.M., Sprague, A.R., Brunt, R.L., Van der Merwe, W.C., Figueiredo, J., Prélat, A., Box, D., Di Celma, C. and Kavanagh, J.P. (2011) Depositional architecture and sequence stratigraphy of the Karoo Basin-floor to shelf edge succession, Laingsburg depocenter, South Africa. Marine and Petroleum Geology, 28, 658-674.

Fonnesu, M., Haughton, P., Felletti, F. and McCaffrey, W. (2015) Short length-scale variability of hybrid event beds and its applied significance. Marine and Petroleum Geology, 67, 583-603. 
Fonnesu, M., Patacci, M., Haughton, P.D.W., Felletti, F. and McCaffrey, W.D. (2016) Hybrid event beds generated by local substrate delamination on a confined-basin floor. Journal of Sedimentary Research, 86, 929-943.

Gardner, M.H., Borer, J.M., Melick, J.J., Mavilla, N., Dechesne, M. and Wagerle, R.N. (2003) Stratigraphic process-response model for submarine channels and related features from studies of Permian Brushy Canyon outcrops, West Texas. Marine and Petroleum Geology, 20(6-8), 757-787.

Gervais, A., Savoye, B., Mulder, T. and Gonthier, E. (2006) Sandy modern turbidite lobes: a new insight from high resolution seismic data. Marine and Petroleum Geology, 23(4), 485-502.

Gingras, M.K., MacEachern, J.A. and Dashtgard, S.E. (2011) Process ichnology and the elucidation of physico-chemical stress. Sedimentary Geology, 237(3-4), 115-134.

Gong, C., Steel, R.J., Wang, Y., Lin, C. and Olariu, C. (2016) Grain size and transport regime at shelf edge as fundamental controls on delivery of shelf-edge sands to deepwater. Earth-Science Reviews, $157,32-60$.

Gorsline, D.S. and Emery, K.O. (1959) Turbidity-current deposits in San Pedro and Santa Monica basins off southern California. Geological Society of America Bulletin, 70(3), 279-290.

Gorsline, D.S. (1978) Anatomy of margin basins; presidential address. Journal of Sedimentary Research, 48(4), 1055-1068.

Grecula, M., Flint, S.S., Potts, G., Wickens, H.D.V. and Johnson, S. (2003a) Partial ponding of turbidite systems in a basin with subtle growth-fold stratigraphy: Laingsburg-Karoo, South Africa. Journal of Sedimentary Research, 73, 603-620.

Grecula, M., Flint, S.S., Wickens, H.D.V. and Johnson, S.D. (2003b) Upward-thickening patterns and lateral continuity of Permian sand-rich turbidite channel fills, Laingsburg Karoo, South Africa. Sedimentology, 50(5), 831-853. 
Grundvåg, S.A., Johannessen, E.P, Helland-Hansen, W. and Plink-Björklund, P. (2014) Depositional architecture and evolution of progradationally stacked lobe complexes in the Eocene Central Basin of Spitsbergen. Sedimentology, 61(2), 535-569.

Hadler-Jacobsen, F., Johannessen, E.P., Ashton, N., Henriksen, S., Johnson, S.D. and Kristensen, J.B. (2005) Submarine fan morphology and lithology distribution: a predictable function of sediment delivery, gross shelf-to-basin relief, slope gradient and basin topography. In: Doré, A.G. and Vinin, B.A. (Eds) Petroleum Geology: North-West Europe and Global Perspectives-Proceedings of the $6^{\text {th }}$ Petroleum Geology Conference, Geological Society, London, pp. 1121-1145.

Haughton, P.D.W., Barker, S.P. and McCaffrey, W.D. (2003) Linked debrites in sand-rich turbidite systems-origin and significance. Sedimentology, 50(3), 459-482.

Heard, T.G. and Pickering, K.T. (2008) Trace fossils as diagnostic indicators of deep-marine environments, Middle Eocene Ainsa-Jaca basin, Spanish Pyrenees. Sedimentology, 55(4), 809-844.

Heard, T.G., Pickering, K.T. and Clark, J.D. (2014) Ichnofabric characterization of a deep-marine clastic system: a subsurface study of the Middle Eocene Ainsa System, Spanish Pyrenees. Sedimentology, 61(5), 1298-1331.

Heller, P.L. and Dickinson, W.R. (1985) Submarine ramp facies model for delta-fed, sand-rich turbidite systems. AAPG Bulletin, 69(6), 960-976.

Ho, V.L., Dorrell, R.M., Keevil, G.M., Burns, A.D. and McCaffrey, W.D. (2018) Pulse propagation in turbidity currents. Sedimentology, 65(2), 620-637.

Hodgson, D.M., Flint, S.S., Hodgetts, D., Drinkwater, N.J., Johannessen, E.P. and Luthi, S.M. (2006) Stratigraphic evolution of a fine-grained submarine fan systems, Tanqua Depocenter, Karoo Basin, South Africa. Journal of Sedimentary Research, 76(1), 20-40.

Hodgson, D.M. (2009) Distribution and origin of hybrid beds in sand-rich submarine fans of the Tanqua depocentre, Karoo Basin, South Africa. Marine and Petroleum Geology, 26(10), 1940-1956. 
Hodgson, D.M., Di Celma, C., Brunt, R.L. and Flint, S.S. (2011) Submarine slope degradation and aggradation and the stratigraphic evolution of channel-levee systems. Journal of the Geological Society, $168,625-628$.

Hunter, R.E. (1977) Terminology of cross-stratified sedimentary layers and climbing-ripple structures. Journal of Sedimentary Research, 47(2), 697-706.

Iverson, R.M. (1997) The physics of debris flows. Reviews of Geophysics, 35, 245-296.

Jobe, Z.R., Lowe, D.R. and Morris, W.R. (2012) Climbing-ripple successions in turbidite systems: depositional environments, sedimentation rates and accumulation times. Sedimentology, 59(3), 867898.

Johannessen, E.P. and Steel, R.J. (2005) Shelf-margin clinoforms and prediction of deepwater sands. Basin Research, 17, 521-550.

Johnson, M.R., Van Vuuren, C.J., Hegenberger, W.F., Key, R. and Show, U. (1996) Stratigraphy of the Karoo Supergroup in southern Africa: an overview. Journal of African Earth Sciences, 23(1), 3-15.

Jones, G.E.D., Hodgson, D.M. and Flint, S.S. (2015) Lateral variability in clinoform trajectory, process regime, and sediment dispersal patterns beyond the shelf-edge rollover in exhumed basin margin-scale clinothems. Basin Research, 27, 657-680.

Jopling, A.V. and Walker, R.G. (1968) Morphology and origin of ripple-drift cross-lamination, with examples from the Pleistocene of Massachusetts. Journal of Sedimentary petrology, 38(4), 971-984.

Kane, I.A. and Hodgson, D.M. (2011) Sedimentological criteria to differentiate submarine channel levee subenvironments: exhumed examples from the Rosario Fm. (Upper Cretaceous) of Baja California, Mexico, and the Fort Brown Fm. (Permian), Karoo basin, S. Africa. Marine and Petroleum Geology, 28(3), 807-823.

Kane, I.A. and Pontén, A.S.M. (2012) Submarine transitional flow deposits in the Paleogene Gulf of Mexico. Geology, 40(12), 1119-1122. 
Kane, I.A., Pontén, A.S., Vangdal, B., Eggenhuisen, J.T., Hodgson, D.M. and Spychala, Y.T. (2017) The stratigraphic record and processes of turbidity current transformation across deep-marine lobes. Sedimentology, 64(5), 1236-1273.

Kineke, G.C., Sternberg, R.W., Trowbridge, J.H. and Geyer, W.R. (1996) Fluid-mud processes on the Amazon continental shelf. Continental shelf research, 16(5-6), 667-696.

Kneller, B.C. and Branney, M.J. (1995) Sustained high-density turbidity currents and the deposition of thick massive sands. Sedimentology, 42(4), 607-616.

Kneller, B. and McCaffrey, W.D. (2003) The interpretation of vertical sequences in turbidite beds: the influence of longitudinal flow structures. Journal of Sedimentary Research, 73, 706-713.

Könitzer, S.F., Davies, S.J., Stephenson, M.H. and Leng, M.J. (2014) Depositional controls on mudstone lithofacies in a basinal setting: implications for the delivery of sedimentary organic matter. Journal of Sedimentary Research, 84(3), 198-214.

Laugier, F.J. and Plink-Björklund, P. (2016) Defining the shelf edge and the three-dimensional shelf edge to slope facies variability in shelf-edge deltas. Sedimentology, 63, 1280-1320.

Lazar, R.O., Bohacs, K.M., Schieber, J., Macquaker, J.H.S. and Demko, T.M. (2015) Mudstone Primer: Lithofacies variations, diagnostic criteria, and sedimentologic-stratigraphic implications at lamina to bedset scales. SEPM (Society for Sedimentary Geology).

Lee, H.J. and Chu, Y.S. (2001) Origin of inner-shelf mud deposit in the southeastern Yellow Sea: Huksan Mud Belt. Journal of Sedimentary Research, 71(1), 144-154.

Loucks, R.G. and Ruppel, S.C. (2007) Mississippian Barnett Shale: Lithofacies and depositional setting of a deep-water shale-gas succession in the Fort Worth Basin, Texas. AAPG bulletin, 91(4), 579-601.

Lowe, D.R. (1982) Sediment gravity flows: II, Depositional models with special reference to the deposits of high-density turbidity current. Journal of Sedimentary Research, 52, 279-297. 
Macquaker, J.H.S. and Gawthorpe, R.L. (1993) Mudstone lithofacies in the Kimmeridge Clay Formation, Wessex Basin, southern England; implications for the origin and controls on the distribution of mudstones. Journal of Sedimentary Research, 63, 1129-1143.

Macquaker, J.H.S, Taylor, K.G. and Gawthorpe, R.L. (2007) High-resolution facies analyses of mudstones: implications for paleoenvironmental and sequence stratigraphic interpretations of offshore ancient mud-dominated successions. Journal of Sedimentary Research, 77(4), 324-339.

McCave, I.N., Manighetti, B. and Robinson, S.G. (1995) Sortable silt and fine sediment size/composition slicing: Parameters for palaeocurrent speed and palaeoceanography. Paleoceanography, 10(3), 593-610.

Morris, E.A., Hodgson, D.M., Brunt, R.L. and Flint, S.S. (2014a) Origin, evolution and anatomy of siltprone submarine external levees. Sedimentology, 61, 1734-1763.

Morris, E.A., Hodgson, D.M., Flint, S.S., Brunt, R.L., Butterworth, P.J. and Verhaeghe, J. (2014b) Sedimentology, stratigraphic architecture, and depositional context of submarine frontal-lobe complexes. Journal of Sedimentary Research, 84, 763-780.

Morris, E.A., Hodgson, D.M., Flint, S.S, Brunt, R.L., Luthi, S.M. and Kolenberg, Y. (2016) Integrating outcrop and subsurface data to assess the temporal evolution of a submarine channel-levee system. AAPG Bulletin, 100(11), 1663-1691.

Mulder, T. and Syvitski, J.P.M. (1995) Turbidity currents generated at river mouths during exceptional discharges to the world oceans. The Journal of Geology, 103(3), 285-299.

Mulder, T. and Alexander, J. (2001) The physical character of subaqueous sedimentary density flows and their deposits. Sedimentology, 48, 269-299.

Mulder, T., Syvitski, J.P.M., Migeon, S., Faugères, J.C. and Savoye, B. (2003) Marine hyperpycnal flows: initiation, behavior and related deposits. A review. Marine and Petroleum Geology, 20, 861-882. 
Mutti, E. and Normark, W.R. (1987) Comparing examples of modern and ancient turbidite systems: problems and concepts. In: Marine clastic sedimentology, Springer, Dordrecht, pp. 1-38.

Nardin, T.R., Hein, F.J., Gorsline, D.S. and Edwards, B.D. (1979) A review of mass movement processes, sediment and acoustic characteristics, and contrasts in slope and base-of-slope systems versus canyon-fan basin floor systems. SEPM Special Publications, 27, 61-73.

Newport, S.M., Jerrett, R.M., Taylor, K.G., Hough, E. and Worden, R.H. (2018) Sedimentology and microfacies of a mud-rich slope succession: in the Carboniferous Bowland Basin, NW England (UK). Journal of the Geological Society, 175(2), 247-262.

Normark, W.R., Hess, G.R., Stow, D.A.V. and Bowen A.J. (1980) Sediment waves on the Monterey Fan levee: a preliminary physical interpretation. Marine Geology, 37, 1-18.

Ogston, A.S., Cacchione, D.A., Sternberg, R.W. and Kineke, G.C. (2000) Observations of storm and river flood-driven sediment transport on the northern California continental shelf. Continental Shelf Research, 20(16), 2141-2162.

Patacci, M., Haughton, P.D. and McCaffrey, W.D. (2014) Rheological complexity in sediment gravity flows forced to decelerate against a confining slope, Braux, SE France. Journal of Sedimentary Research, 84(4), 270-277.

Paumard, V., Bourget, J., Payenberg, T., George, A.D., Ainsworth, B.R., Lang, S. and Posamentier, H.W. (2020) Controls on deep-water sand delivery beyond the shelf edge: Accommodation, sediment supply, and deltaic process regime. Journal of Sedimentary Research, 90, 104-130.

Palanques, A., de Madron, X.D., Puig, P., Fabres, J., Guillén, J., Calafat, A., Canals, M., Heussner, S. and Bonnin, J. (2006) Suspended sediment fluxes and transport processes in the Gulf of Lions submarine canyons. The role of storms and dense water cascading. Marine Geology, 234(1-4), 43-61.

Plink-Björklund, P. and Steel, R. (2002) Sea-level fall below the shelf edge, without basin-floor fans. Geology, 30(2), 115-118. 
Plint, G.A. (2014) Mud dispersal across a Cretaceous prodelta: storm-generated, wave-enhanced sediment gravity flows inferred from mudstone microtexture and microfacies. Sedimentology, 61(3), 609-647.

Pickering, K.T. and Cantalejo, B. (2015) Deep-marine environments of the middle Eocene upper Hecho group, Spanish Pyrenees: introduction. Earth Science Reviews, 144, 1-9.

Piper, D.J.W. (1978) Turbidite muds and silts on deep-sea fans and abyssal plains. In: Stanley, D.J. and Kelling, G. (Eds) Sedimentation in submarine canyons, fans, and trenches, Stroudsburg, Pennsylvania, Dowde, Hutchinson \& Ross, pp. 163-176.

Porębski, S.J. and Steel, R.J. (2003) Shelf-margin deltas: their stratigraphic significance and relation to deepwater sands. Earth Science Reviews, 62(3-4), 283-326.

Posamentier, H.W. and Kolla, V. (2003) Seismic geomorphology and stratigraphy of depositional elements in deep-water settings. Journal of Sedimentary Research, 73, 367-388.

Posamentier, H.W. and Walker, R. (2006) Deep-water turbidites and submarine fans. In: Posamentier H.W. and Walker R. (Eds) Facies models revisited, SEPM, Special Publication 84, pp. 399-520.

Poyatos-Moré, M., Jones, G.D., Brunt, R.L., Hodgson, D.M., Wild, R.J. and Flint, S.S. (2016) Muddominated basin-margin progradation: Processes and implications. Journal of Sedimentary Research, $86,863-878$.

Poyatos-Moré, M., Jones, G.D., Brunt, R.L., Tek, D.E., Hodgson, D.M. and Flint, S.S. (2019) Clinoform architecture and along-strike facies variability through an exhumed erosional to accretionary basin margin transition. Basin Research, 31(5), 920-947.

Prather, B.E., O'Byrne, C., Pirmez, C. and Sylvester, Z. (2017) Sediment partitioning, continental slopes and base-of-slope systems. Basin Research, 29(3), 394-416. 
Prélat, A., Hodgson, D.M., and Flint, S.S. (2009) Evolution, architecture and hierarchy of distributary deep-water deposits: a high resolution outcrop investigation from the Permian Karoo Basin, South Africa. Sedimentology, 56(7), 2132-2154.

Prélat, A. and Hodgson, D.M. (2013) The full range of turbidite bed thickness patterns in submarine lobes: controls and implications. Journal of the Geological Society, London, 170(1), 209-214.

Puig, P., Ogston, A.S., Mullenbach, B.L., Nittrouer, C.A. and Sternberg, R.W. (2003) Shelf-to-canyon sediment-transport processes on the Eel continental margin (northern California). Marine Geology, 193(1-2), 129-149.

Pyles, D.R. (2008) Multiscale stratigraphic analysis of a structurally confined submarine fan: Carboniferous Ross Sandstone, Ireland. AAPG bulletin, 92(5), 557-587.

Pysklywec, R.N. and Mitrovica, J.X. (1999) The role of subduction-induced subsidence in the evolution of the Karoo Basin. The Journal of Geology, 107(2), 155-164.

Reading, H.G. and Richards, M. (1994) Turbidite systems in deep-water basin margins classified by grain size and feeder system. AAPG bulletin, 78(5), 792-822.

Schieber, J. (1994) Evidence for high-energy events and shallow-water deposition in the Chattanooga Shale, Devonian, central Tennessee, USA. Sedimentary Geology, 93(3-4), 193-208.

Schieber, J. (1999) Distribution and deposition of mudstone facies in the Upper Devonian Sonyea Group of New York. Journal of Sedimentary Research, 69(4), 909-925.

Schieber, J., Southard, J.B. and Schimmelmann, A. (2010) Lenticular shale fabrics resulting from intermittent erosion of water-rich muds-Interpreting the rock record in the light of recent flume experiments. Journal of Sedimentary Research, 80(1), 119-128.

Sinclair, H.D. and Tomasso, M. (2002) Depositional evolution of confined turbidite basins. Journal of Sedimentary Research, 72(4), 451-456. 
Sixsmith, P.J., Flint, S.S., Wickens, H.D. and Johnson, S.D. (2004) Anatomy and stratigraphic development of a basin floor turbidite system in the Laingsburg Formation, Karoo Basin, main Karoo Basin, South Africa. Journal of Sedimentary Research, 74, 239-254.

Smith, R.M.H. (1990) A review of stratigraphy and sedimentary environments of the Karoo Basin of South Africa. Journal of African Earth Sciences, 16(1-2), 143-169.

Spychala, Y.T., Hodgson, D.M., Flint, S.S. and Mountney, N.P. (2015) Constraining the sedimentology and stratigraphy of submarine intraslope lobe deposits using exhumed examples from the Karoo Basin, South Africa. Sedimentary Geology, 322, 67-81.

Spychala, Y.T., Hodgson, D.M., Stevenson, C.J. and Flint, S.S. (2017) Aggradational lobe fringes: The influence of subtle intrabasinal seabed topography on sediment gravity flow processes and lobe stacking patterns. Sedimentology, 64, 582-608.

Suter, J.R., Berryhill, H.L. and Penland, S. (1987) Late Quaternary sea-level fluctuations and depositional sequences, southwest Louisiana continental shelf. In: Sea-Level and Coastal Evolution (Eds D. Nummendal, O.H. Pilkey and J.D. Howard). SEPM Special Publication, 40.

Surlyk, F. (1987) Slope and deep shelf gully sandstones, Upper Jurassic, East Greenland. AAPG Bulletin, 71(4), 464-475.

Steel, R.J., Porebski, S.J., Plink-Bjorklund, P., Mellere, D. and Schellpeper, M. (2003) Shelf-edge delta types and their sequence-stratigraphic relationships. Shelf Margin Deltas and Linked Down Slope Petroleum Systems: Global Significance and Future Exploration Potential, 23, pp. 205-230.

Stevenson, C.J., Jackson, C.A.L., Hodgson, D.M., Hubbard, S.M. and Eggenhuisen, J.T. (2015) Deepwater sediment bypass. Journal of Sedimentary Research, 85(9), 1058-1081.

Stow, D.A.V. and Shanmugam, G. (1980) Sequence of structures in fine-grained turbidites: comparison of recent deep-sea and ancient flysch sediments. Sedimentary Geology, 25(1-2), 23-42. 
Sweet, M.L., Gaillot, G.T., Jouet, G., Rittenour, T.M., Toucanne, S., Marsset, T. and Blum, M.D. (2019) Sediment routing from shelf to basin floor in the Quaternary Golo System of Eastern Corsica, France, western Mediterranean Sea. GSA Bulletin.

Sylvester, Z., Deptuck, M.E., Prather, B.E., Pirmez, C. and O’Byrne, C.J. (2012) Seismic stratigraphy of a shelf-edge delta and linked submarine channels in the Northeastern Gulf of Mexico. In: Prather B. E., Deptuck M.E., Mohrig D.C., van Hoorn B. and Wynn R.B. (Eds) Application of the Principles of Seismic Geomorphology to Continental-Slope and Base-of-Slope Systems: Case Studies From Seafloor and Near-Seafloor Analogues, SEPM Special Publication 99, pp. 31-59.

Talling, P.J., Amy, L.A., Wynn, R.B., Peakall, J. and Robinson, M. (2004) Beds comprising debrite sandwiched within co-genetic turbidite: origin and widespread occurrence in distal depositional environments. Sedimentology, 51(1), 163-194.

Talling, P.J., Masson, D.G., Sumner, E.J. and Malgesini, G. (2012) Subaqueous sediment density flows: Depositional processes and deposit types. Sedimentology, 59(7), 1937-2003.

Tankard, A., Welsink, H., Aukes, P., Newton, R. and Stettler, E. (2009) Tectonic evolution of the Cape and Karoo basins of South Africa. Marine and Petroleum Geology, 26, 1379-1412.

Taylor, A.M. and Goldring, R. (1993) Description and analysis of bioturbation and ichnofabric. Journal of the Geological Society, London, 150, 358-368.

Terlaky, V., Rocheleau, J. and Arnott, R.W.C. (2016) Stratal composition and stratigraphic organisation of stratal elements in an ancient deep-marine basin-floor succession, Neoproterozoic Windermere Supergroup, British Columbia, Canada. Sedimentology, 63(1), 136-175.

Trabucho-Alexandre, J., Dirkx, R., Veld, H., Klaver, G. and de Boer, P.L. (2012) Toarcian black shales in the Dutch Central Graben: record of energetic, variable depositional conditions during an oceanic anoxic event. Journal of sedimentary Research, 82(2), 104-120. 
Traykovski, P., Geyer, W.R., Irish, J.D. and Lynch, J.F. (2000) The role of wave-induced density-driven fluid mud flows for cross-shelf transport on the Eel River continental shelf. Continental Shelf Research, 20(16), 2113-2140.

Van der Merwe, W.C., Hodgson, D.M. and Flint, S.S. (2009) Widespread syn-sedimentary deformation on a muddy deep-water basin-floor: The Vischkuil Formation (Permian), Karoo Basin, South Africa. Basin Research, 21, 389-406.

Van der Merwe, W.C., Flint, S.S. and Hodgson, D.M. (2010) Sequence stratigraphy of an argillaceous, deepwater basin plain succession: Vischkuil Formation (Permian), Karoo Basin, South Africa. Marine and Petroleum Geology, 27, 321-333.

Van der Merwe, W.C., Hodgson, D.M., Brunt, R.L. and Flint, S.S. (2014) Depositional architecture of sand-attached and sand-detached channel-lobe transition zones on an exhumed stepped slope mapped over a $2500 \mathrm{~km}^{2}$ area. Geosphere, 10, 1076-1093.

Veevers, J.J., Cole, D.I. and Cowan, E.J. (1994) Southern Africa: Karoo Basin and Cape Fold Belt. In: Veevers, J.J. and Powell, C.M. (Eds) Permian-Triassic Pangean Basins and foldbelts along the Panthalassan margin of Gondwanaland, Geological Society America, Memoir, 184, pp. 223-279.

Viljoen, J.H.A. (1994) Sedimentology of the Collingham Formation, Karoo Supergroup. South African Journal of Geology, 97(2), 167-183.

Visser, J.N.J. (1992) Deposition of the early to late Permian Whitehill Formation during a sea-level highstand in a juvenile foreland basin. South African Journal of Geology, 95 (5-6), 181-193.

Visser, J.N.J. and Prackelt, H.E. (1996) Subduction, mega-shear systems and Late Palaeozoic basin development in the African segment of Gondwana. Geologische Rundschau, 85(4), 632-646.

Walsh, J.P. and Nittrouer, C.A. (1999) Observations of sediment flux to the Eel continental slope, northern California. Marine Geology, 154(1-4), 55-68. 
Wells, J.T. and Coleman, J.M. (1981) Physical processes and fine-grained sediment dynamics, coast of Surinam, South America. Journal of Sedimentary Research, 51(4), 1053-1068.

Wetzel, A. (1984) Bioturbation in deep-sea fine-grained sediments: influence of sediment texture, turbidite frequency and rates of environmental change. Geological Society, London, Special Publications, 15(1), 595-608.

Wetzel, A. and Uchman, A. (2001) Sequential colonization of muddy turbidites in the Eocene Beloveža Formation, Carpathians, Poland. Palaeogeography, Palaeoclimatology, Palaeoecology, 168(1-2), 171186.

Wright, L.D., Friedrichs, C.T., Kim, S.C. and Scully, M.E. (2001) Effects of ambient currents and waves on gravity-driven sediment transport on continental shelves. Marine Geology, 175(1-4), 25-45.

Wynn, R.B., Masson, D.G., Stow, D.A. and Weaver, P.P. (2000) The Northwest African slope apron: a modern analogue for deep-water systems with complex seafloor topography. Marine and Petroleum Geology, 17(2), 253-265. 


\section{FIGURES}
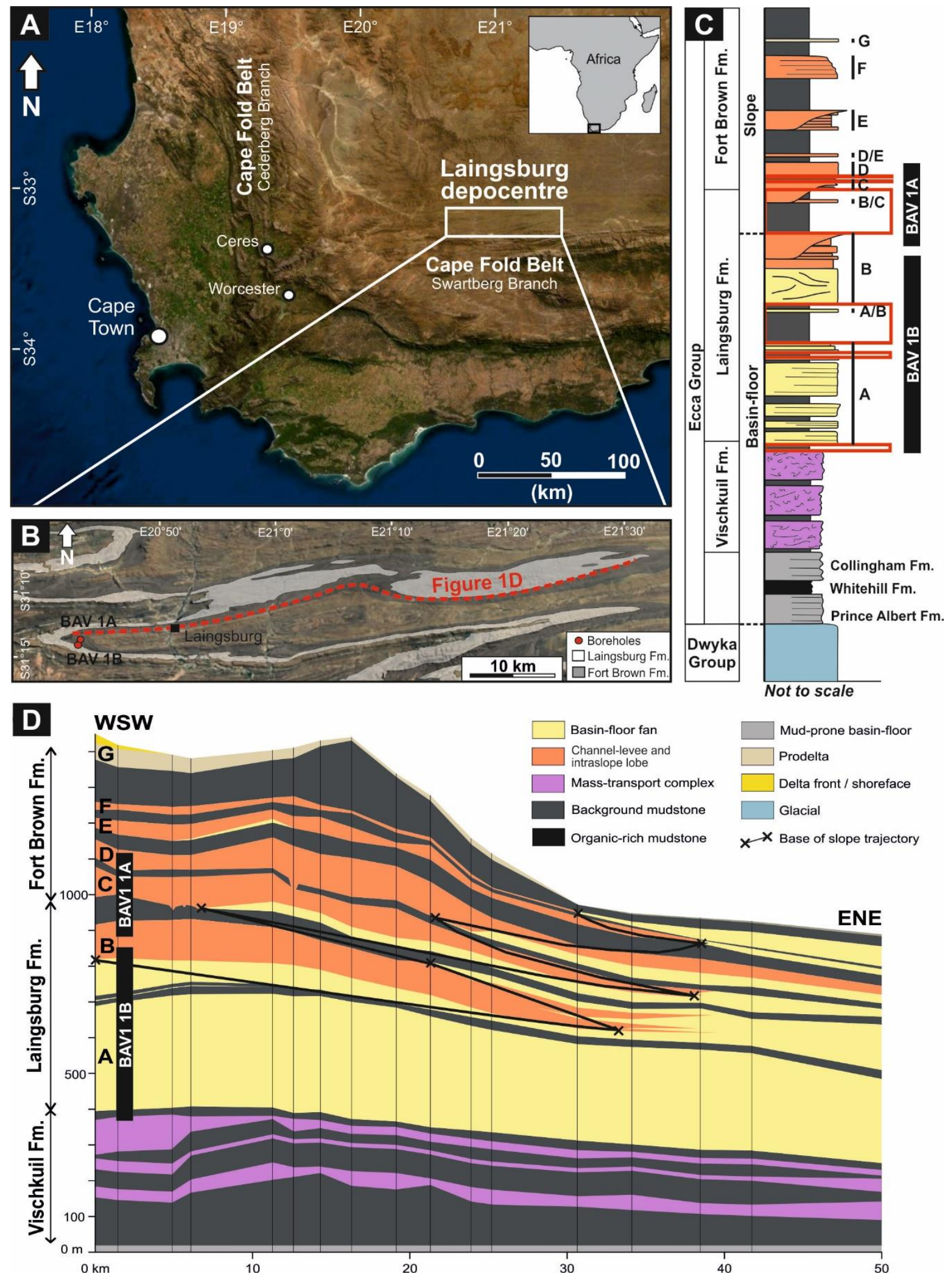
Figure 1: A) Satellite view of southwest South Africa with location of the study area (Laingsburg depocentre, Karoo Basin) indicated by the white square. B) Satellite view of Laingsburg depocentre showing the outcrop belt of the Permian Laingsburg and Fort Brown formations, and the location of the two cores described in this study (BAV 1A, BAV 1B). C) Schematic stratigraphic log of the Karoo Supergroup in the Laingsburg depocentre. The six mudstone units presented in this study are indicated by the red squares. The stratigraphic package encompassed by the two cores is indicated by the black squares. Redrawn after Brooks et al. (2018a). D) Stratigraphic correlation of the Upper Ecca Group in the Laingsburg depocentre. The location of the panel is shown in Figure 1B. The projected drilling location of the two cores described in this study (BAV 1A, BAV 1B) is indicated. Redrawn after Poyatos-Moré et al. (2019). 


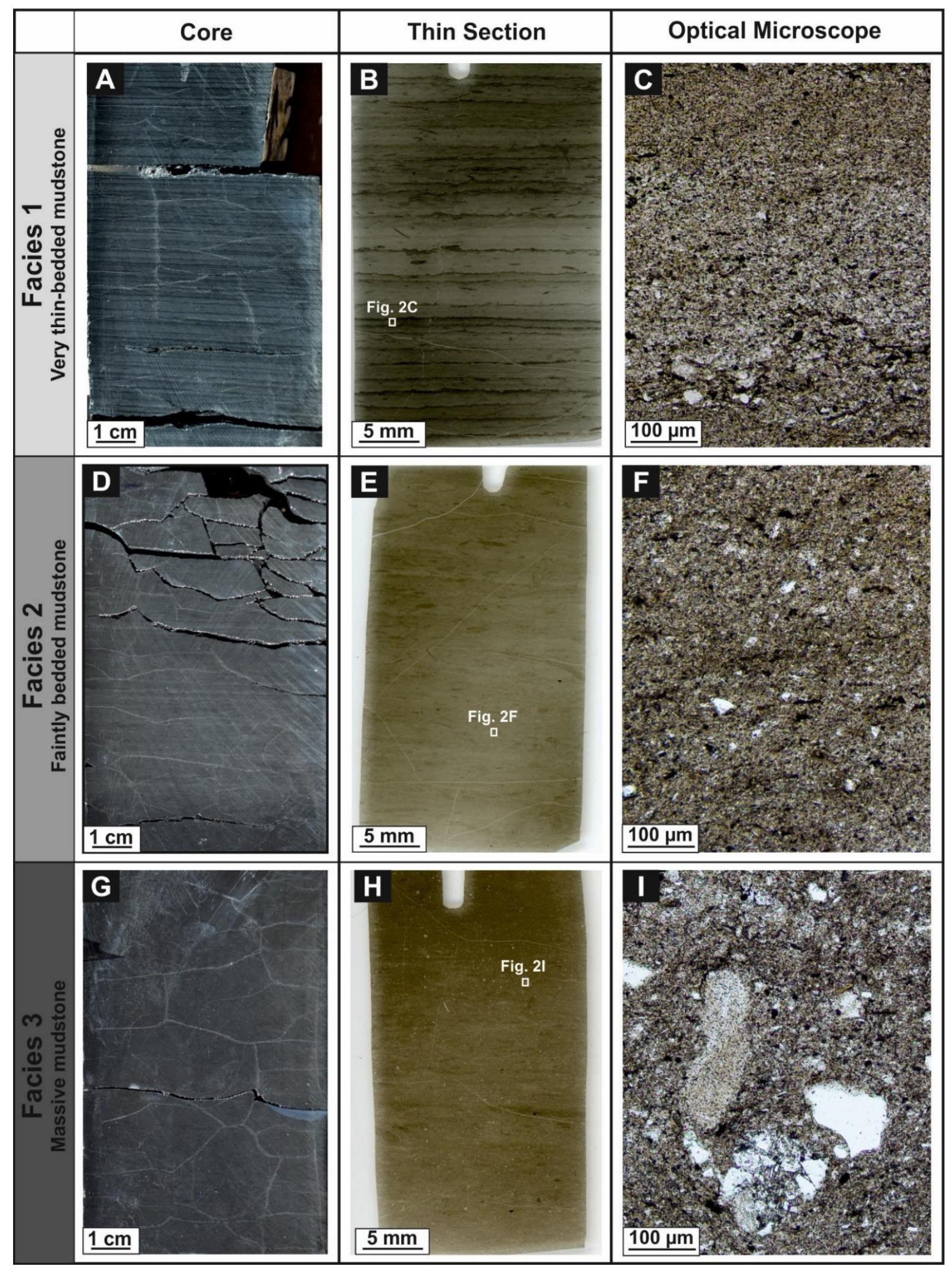


Figure 2: Illustrations of the three mudstone facies identified in BAV 1A and BAV 1B cores. A, D and $\mathrm{G}$ are wet core photographs. B, E and $\mathrm{H}$ are thin-section scans. C, F, and I are photomicrographs (PPL). White squares in thin-section scans indicate locations of photomicrographs. A) Facies 1 (very thinbedded mudstone) characterised by stacked millimetre-thick beds laterally continuous at core scale (BAV 1B; 211.63 m). B) Variably graded stacked very thin beds of Facies 1. C) Zoom view of the texture of Facies 1. Note the normal grading is even observable at microscopic scale. D) Facies 2 (faintly bedded mudstone) characterised by stacked millimetre-thick bioturbated beds laterally discontinuous at core scale (BAV 1B; 198.46 m). E) Stacked bioturbated beds. Note the gradational bed boundaries due to bioturbation. F) Zoom view of the texture of Facies 2. Texture is poorly sorted because of bioturbation. G) Facies 3 (massive mudstone) characterised by a massive texture at core scale (BAV 1B; $172.80 \mathrm{~m})$. H) Note the "starry-night" texture at thin-section scale. I) Zoom view of the texture of Facies 3. Texture consists of floating outsized very fine to medium sand size particles (mudstone clasts, quartz, volcanic rock fragments) in a matrix of poorly-sorted mud. 


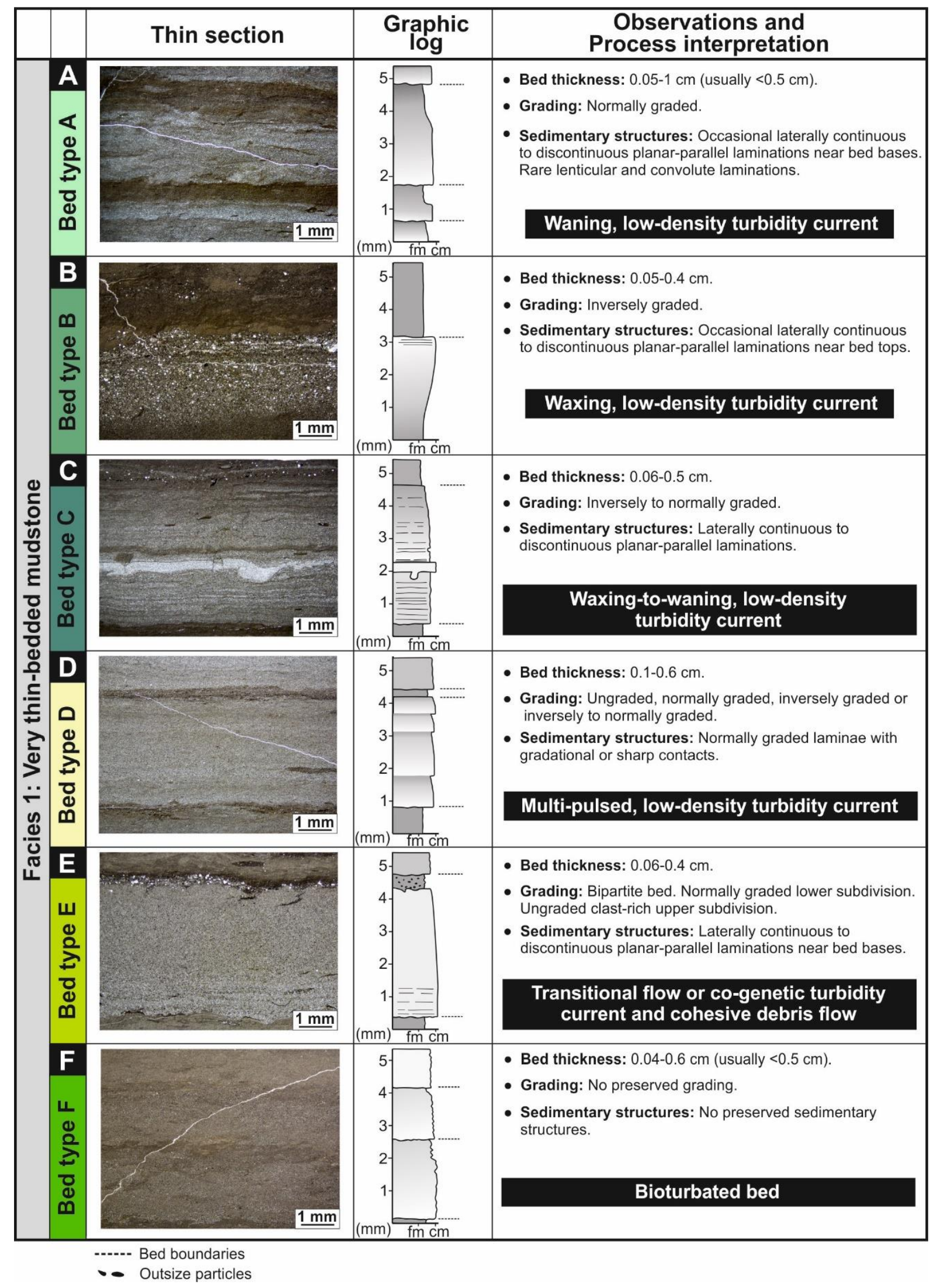


Figure 3: Representative photomicrographs (PPL), descriptions, and process interpretations of the six bed types identified in Facies 1 (very thin-bedded mudstone). A) Bed type A is normally graded, and interpreted as deposited by waning, low-density turbidity current. B) Bed type B is inversely graded, and interpreted as deposited by waxing, low-density turbidity current. C) Bed type $\mathrm{C}$ is inversely to normally graded, and interpreted as deposited by waxing-to-waning, low-density turbidity currents. D) Bed type D is characterised by stacked normally graded laminations, and interpreted as deposited by multi-pulsed, low-density turbidity currents. E) Bed type E exhibits an internal bipartite microstratigraphy, and is interpreted as deposited by transitional flows or co-genetic turbidity currents and cohesive debris flows. F) Bed type F grading and sedimentary structures are not preserved due to strong bioturbation. This type of bed may have been primarily deposited by any of the processes responsible for the accumulation of Bed types A to D before intense reworking by bioturbation. 


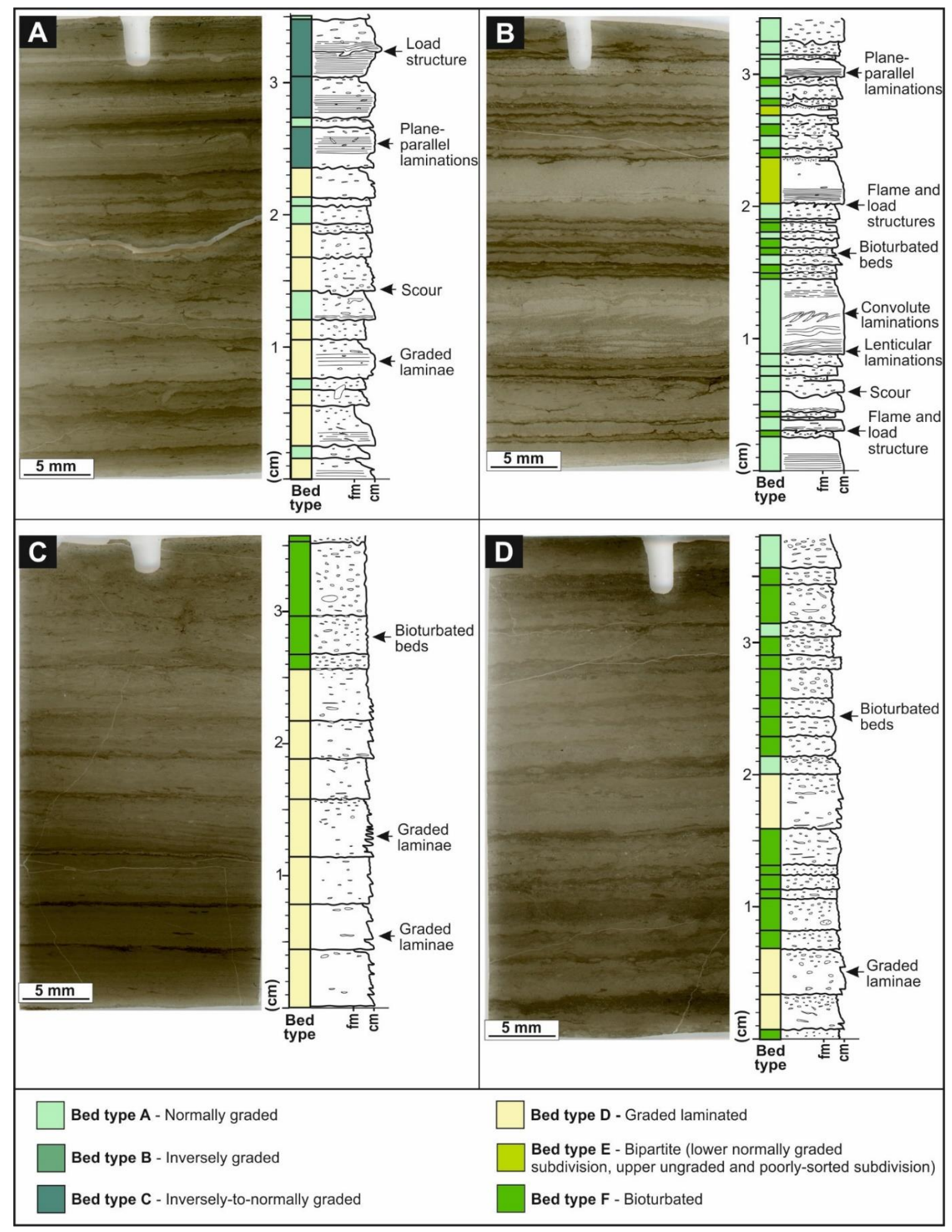


Figure 4: Thin-section scans illustrating the bed stacking pattern of Facies 1 (very thin-bedded mudstone). A) Basin floor, Vischkuil/A mudstone (BAV 1B; $505.25 \mathrm{~m}$ ). Note the dominance of graded laminated beds (Bed type D), and the inversely to normally graded beds (Bed type C) near the top. B) Base-of-slope, A/B mudstone (BAV 1B; $167.57 \mathrm{~m}$ ). Note the dominance of normally graded beds (Bed type A). C) Lower slope, B/C mudstone (BAV 1B; $198.79 \mathrm{~m}$ ). Note the dominance of graded laminated beds (Bed type D). D) Mid slope, C/D mudstone (BAV 1A; $72.50 \mathrm{~m}$ ). Note the dominance of bioturbated beds (Bed type F), with rare intercalated normally graded (Bed type A) and graded laminated (Bed type D) beds. 

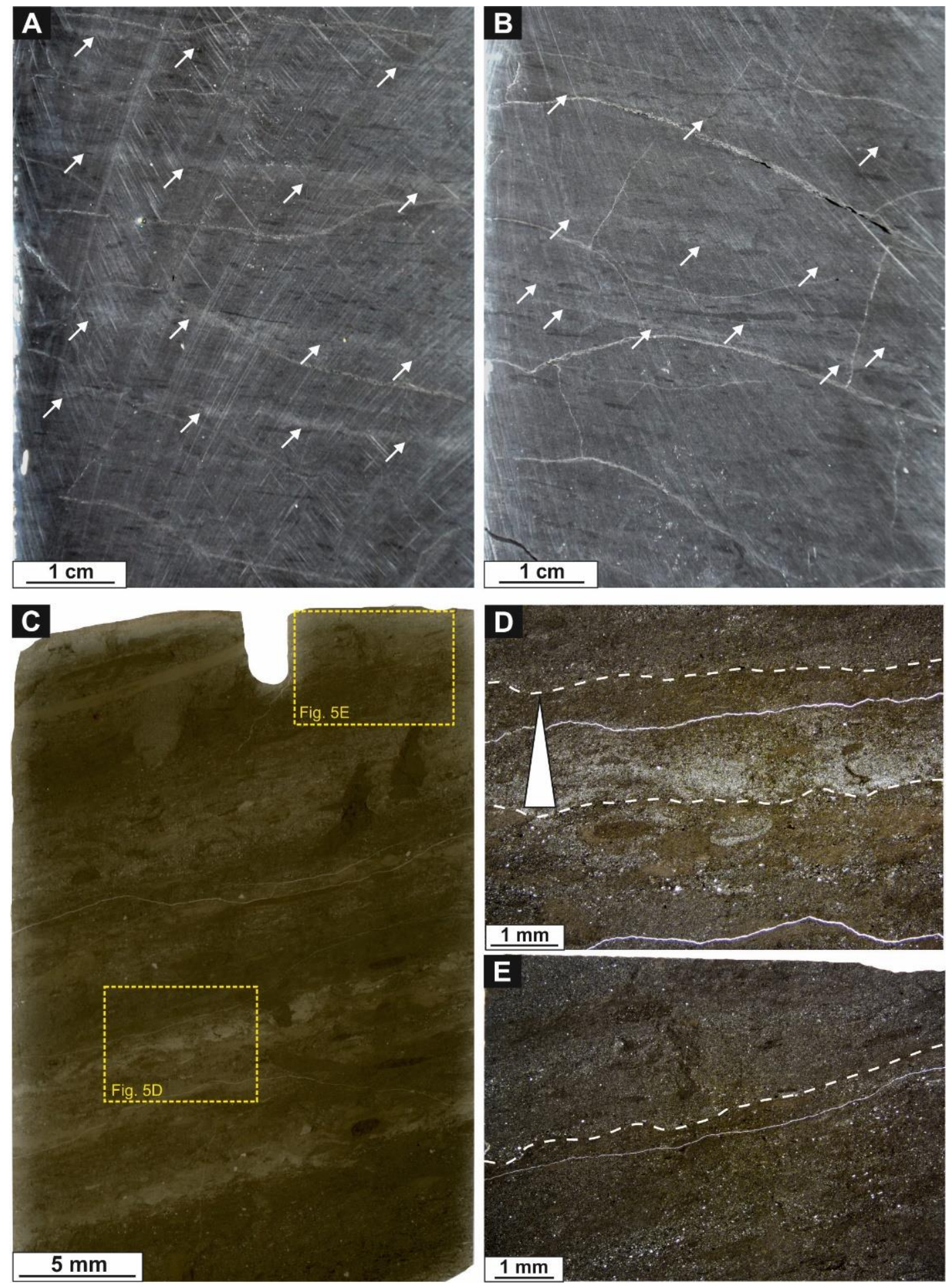

Figure 5: Examples of the key features of Facies 2 (faintly bedded mudstone). A and B are wet core photographs. $\mathrm{C}$ is a thin-section scan. D and $\mathrm{E}$ are photomicrographs (PPL). A) Laterally discontinuous very thin beds. White arrows indicate the base of mudstone beds (BAV 1A; $231.10 \mathrm{~m}$ ). B) Laterally discontinuous very thin beds. White arrows indicate the base of mudstone beds (BAV 1A; $217.35 \mathrm{~m}$ ). C) Stacked laterally discontinuous very thin beds (BAV 1A; $79.10 \mathrm{~m}$ ). D) Zoom on the thin section presented in part $\mathrm{C}$. Note the preserved normal grading, despite the intense bioturbation. E) Zoom on the thin section presented in part C. Note the remnant bedding. 

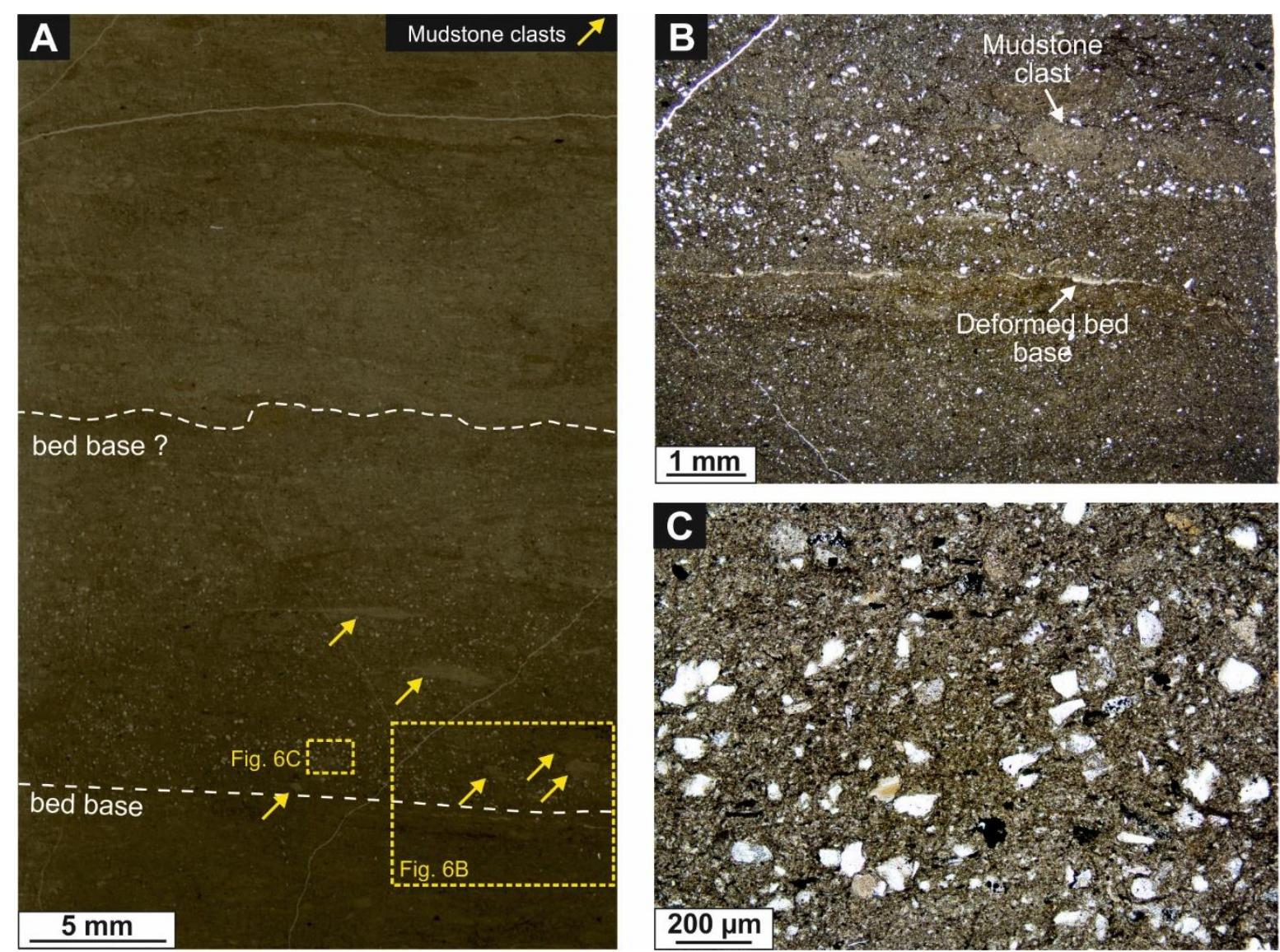

Figure 6: Example of Facies 3 (massive mudstone) with a "starry-night" texture (BAV 1A; 219.25 m).

A) Thin-section scan. Note the "starry-night" texture in the bed interpreted as deposited from lowstrength, cohesive debris flow, prior to intense post-depositional bioturbation. B) Photomicrograph (PPL) showing a zoom view of the dashed square in part A. Note the example of a deformed bed base, and the poorly sorted texture. C) Photomicrograph (PPL) showing a zoom view of the dashed square in part A, and illustrating the poorly sorted texture within the bed. Mineralogy consists of quartz and feldspar crystals, volcanic and metamorphic rock fragments, and mudstone clasts. 

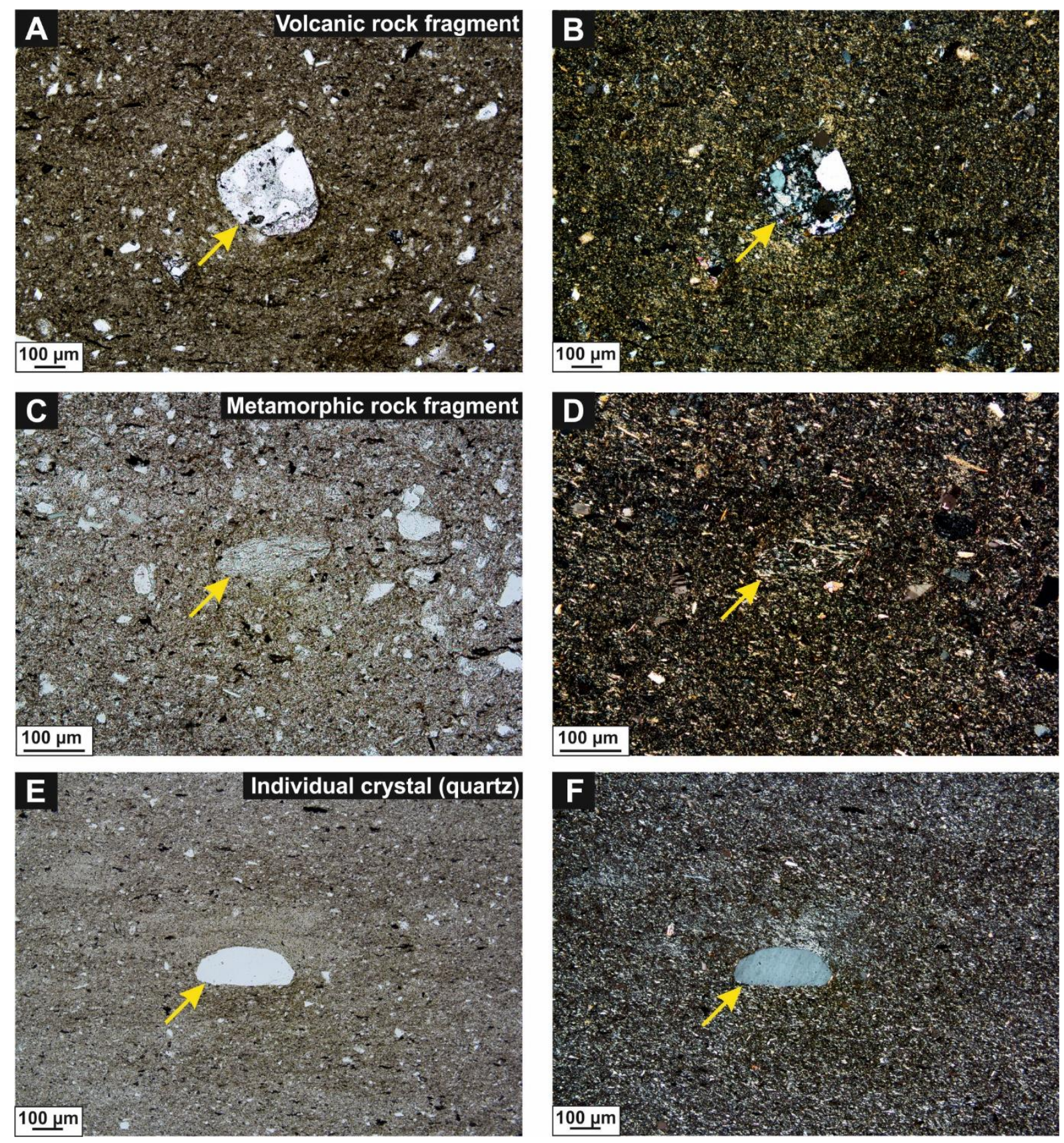

Figure 7: Photomicrographs showing examples of different types of outsized particles (yellow arrows) identified in thin sections of Facies 3 (massive mudstone). A, B) Volcanic rock fragment of medium sand size in a matrix of mud (PPL and CPL) (BAV 1B; $172.80 \mathrm{~m}$ ). Note the differential compaction around the outsized particle. C, D) Metamorphic rock fragment of fine sand size in a matrix of mud (PPL and CPL) (BAV 1B; $172.80 \mathrm{~m}$ ). Note the foliations within the fragment. E, F) Crystal of quartz of fine sand size in a matrix of mud (PPL and CPL) (BAV 1B; $203.10 \mathrm{~m}$ ). 

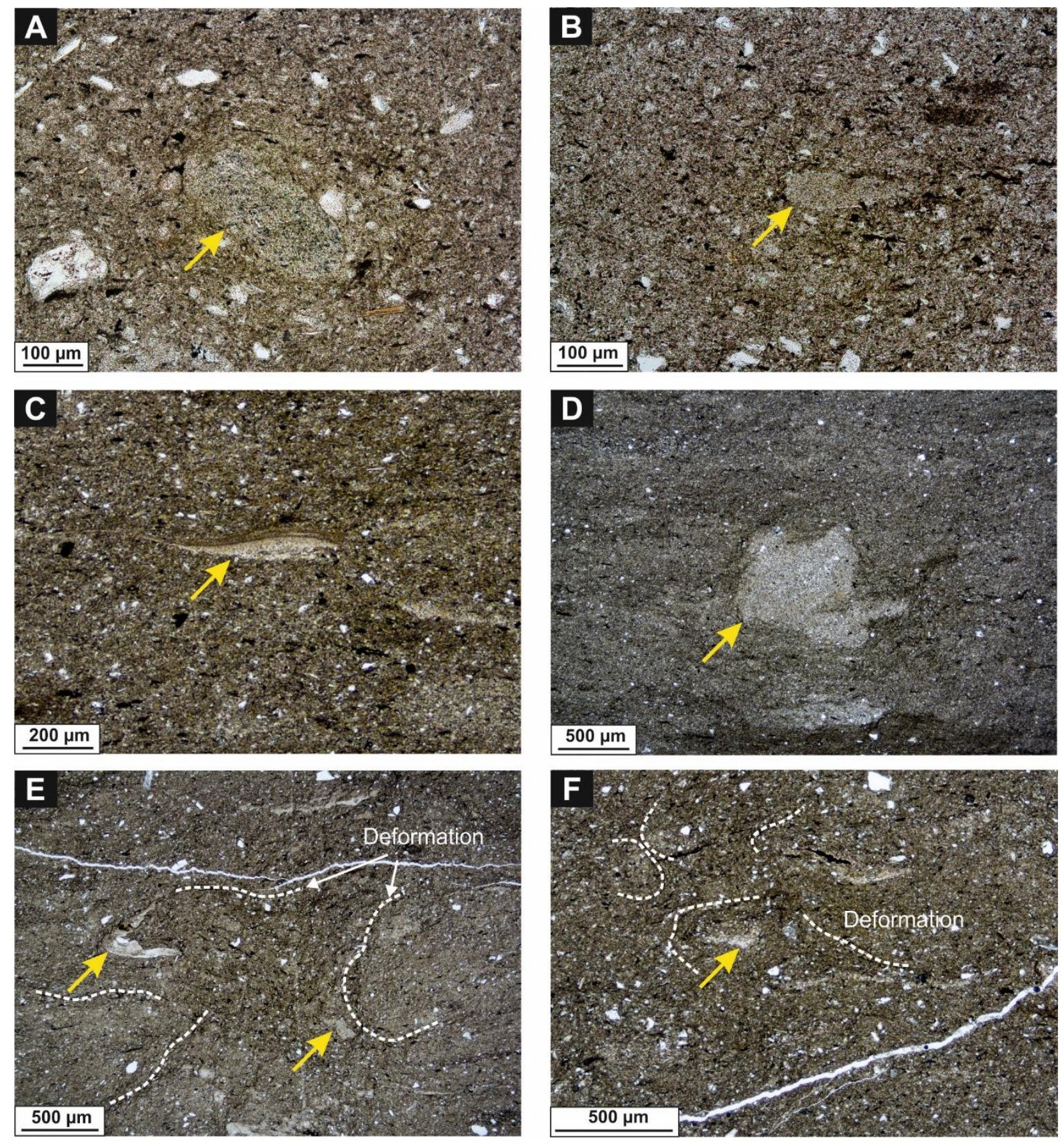

Figure 8: Photomicrographs showing examples of mudstone clasts (yellow arrows) and deformations (white dotted lines) identified in thin sections (PPL) of Facies 3 (massive mudstone). A) Rounded mudstone clast in a matrix of mud (BAV $1 B ; 172.80 \mathrm{~m})$. B) Sub-rounded mudstone clast in a matrix of mud (BAV 1B; $172.80 \mathrm{~m}$ ). C) Sub-angular mudstone clast in a matrix of mud (BAV 1B; $203.10 \mathrm{~m}$ ). D) Mudstone clast characterised by plastic deformations in a matrix of mud (BAV 1B; $181.85 \mathrm{~m}$ ). E) Deformation within F3 marked by circular and arcuate grains alignment (BAV 1B; $177.81 \mathrm{~m}$ ). Note the highly deformed mudstone clast to the left. F) Deformation in F3 marked by circular and arcuate grains alignment (BAV 1A; $224.15 \mathrm{~m})$. 


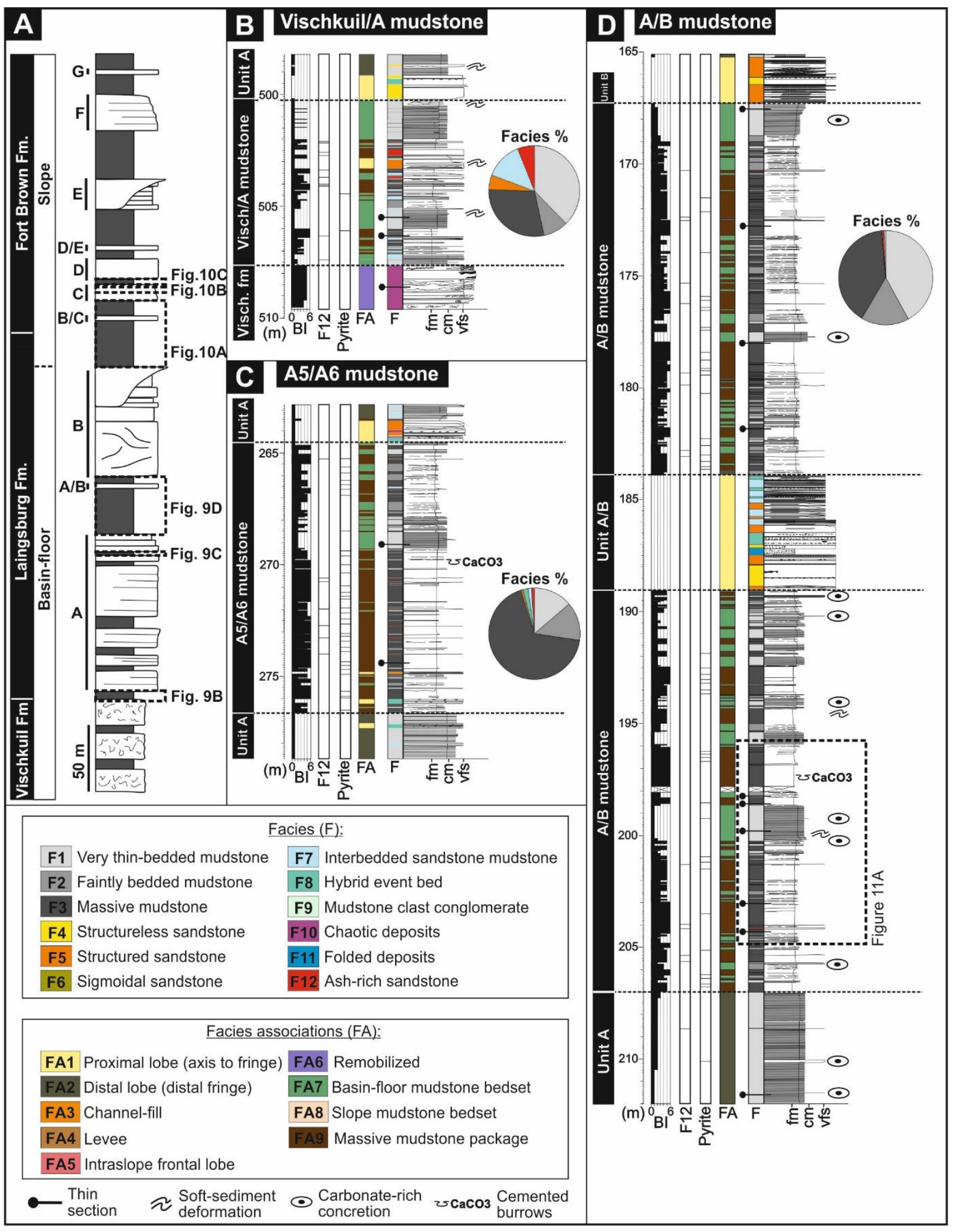


Figure 9: Sedimentological logs of the three basin-floor to base-of-slope mudstone units (from BAV 1B). A) Schematic stratigraphic log of the Upper Ecca Group from the Laingsburg depocentre, with locations of the studied regional mudstone units. B) Basin floor, Vischkuil/A mudstone unit. C) Basin floor, A5/A6 mudstone unit. D) Basin-floor to base-of-slope, A/B mudstone unit. The pie chart represents facies percentage for the entire A/B mudstone unit. Logs include facies $(F)$, facies associations (FA), bioturbation index (BI), presence of pyrite nodules, presence of ash-rich sandstones (F12), and locations of thin-sections. Bioturbation index scale from Taylor and Goldring (1993). $\mathrm{fm}=$ fine mudstone, $\mathrm{cm}=$ coarse mudstone, $\mathrm{vfs}=$ very fine sandstone. 


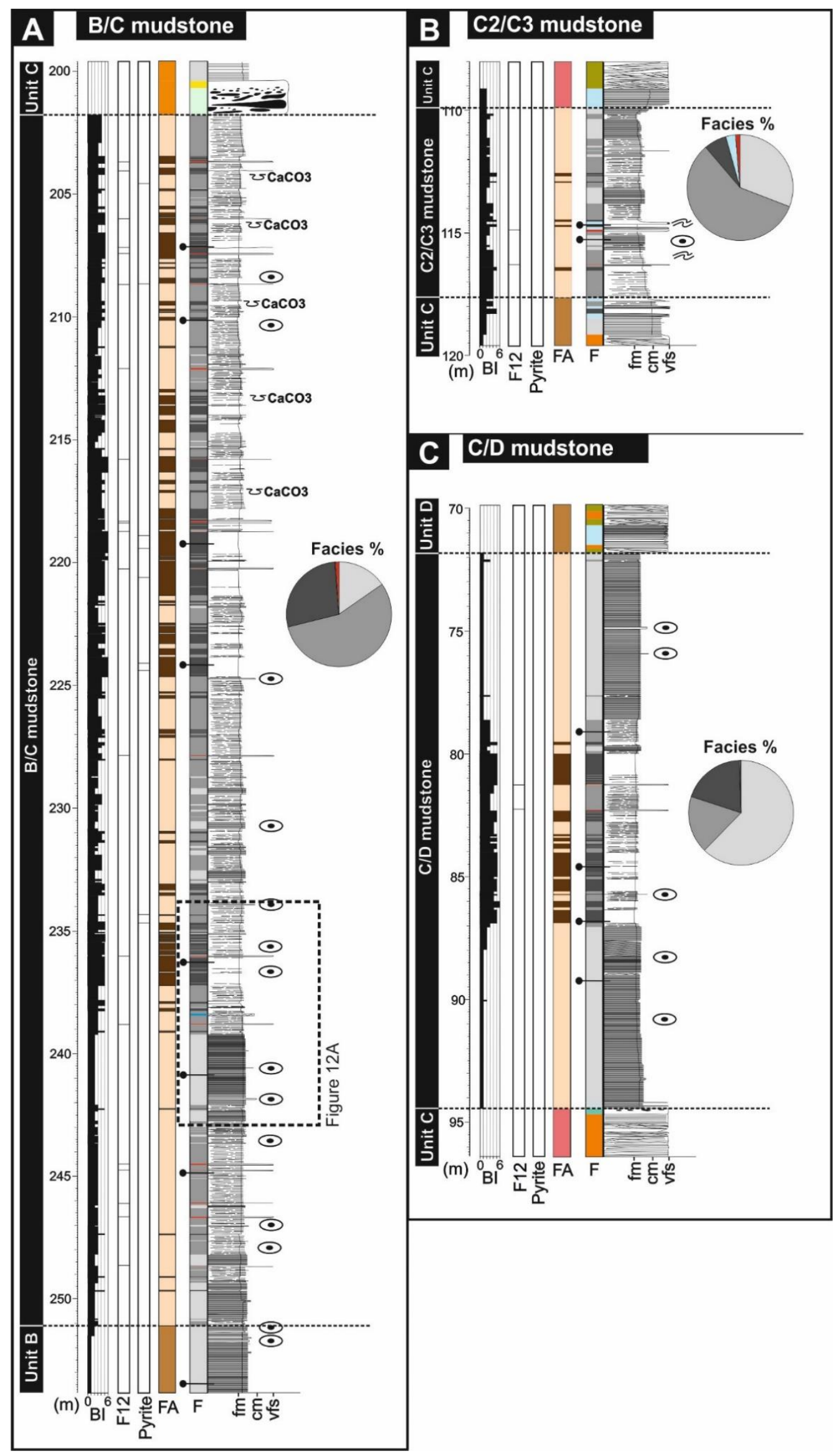


Figure 10: Sedimentological logs of the three slope mudstone units (from BAV 1A). See stratigraphic locations in Figure 9A. See legend in Figure 9. A) Lower slope, B/C mudstone unit. B) Mid slope, C2/C3 mudstone unit. C) Mid slope, C/D mudstone unit. Bioturbation index scale from Taylor and Goldring (1993). Logs include facies (F), facies associations (FA), bioturbation index (BI), presence of pyrite nodules, presence of ash-rich sandstones (F12), and locations of thin-sections. Bioturbation index scale from Taylor and Goldring (1993). $\mathrm{fm}=$ fine mudstone, $\mathrm{cm}=$ coarse mudstone, $\mathrm{vfs}=$ very fine sandstone. 


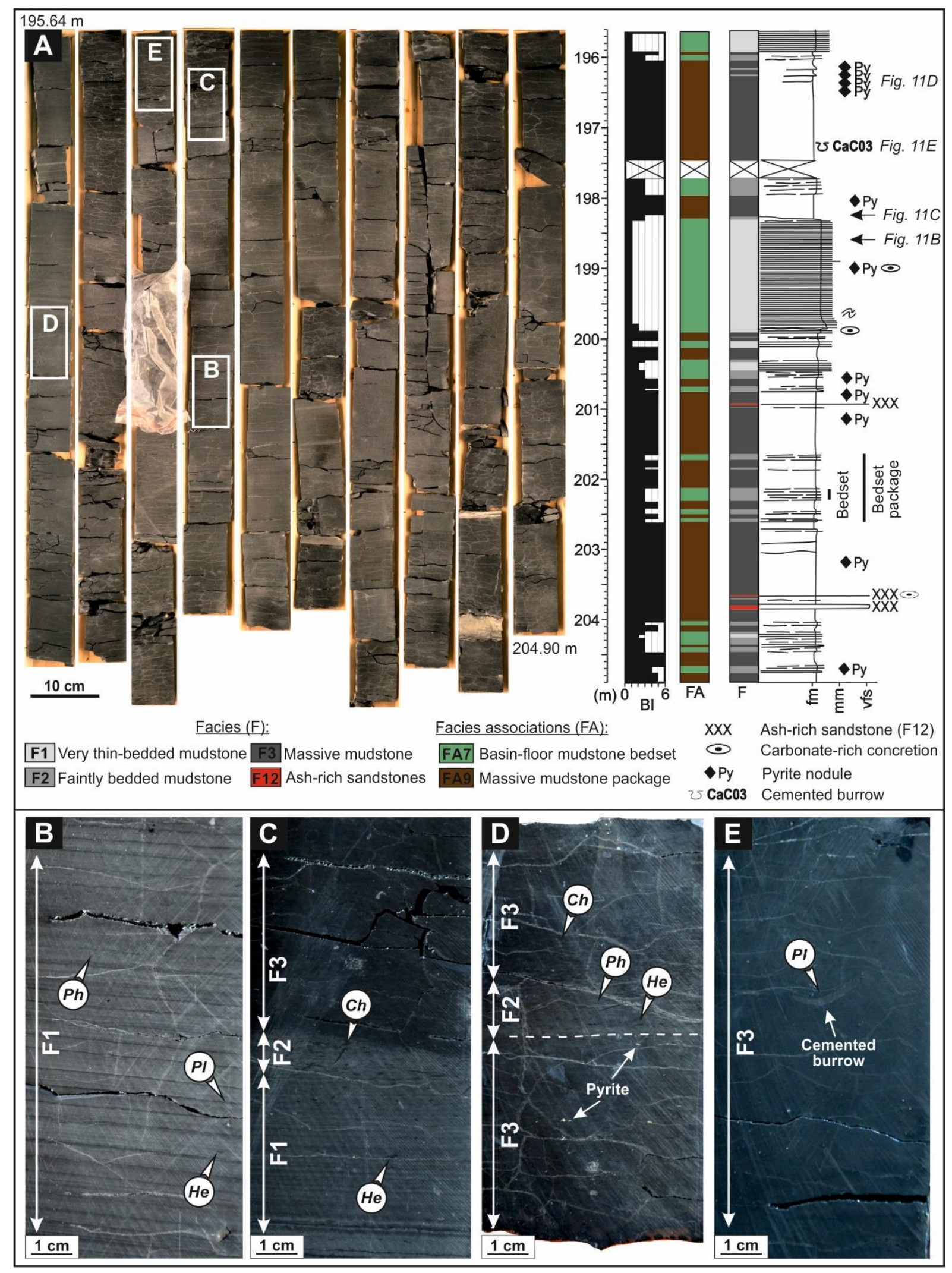


Figure 11: A) Representative $9.26 \mathrm{~m}$-thick core section and sedimentological log of the basin-floor to base-of-slope A/B mudstone unit (see Figure 9 for stratigraphic position). Note the repeated and predictable facies stacking pattern, with individual very thin beds of F1 and F2 that stack to form basinfloor mudstone bedsets (FA7), vertically separated by massive packages of F3 with common ash-rich sandstones (F12) and pyrite nodules to form massive mudstone packages (FA9). Bioturbation index scale from Taylor and Goldring (1993). B) Close-up view of FA7 dominated by F1. C) Close-up view of a bioturbated vertical transition from FA7 dominated by F1 and F2, to darker and more bioturbated FA9 dominated by F3. D) Close-up view of an isolated very thin bed of F2 within FA9 dominated by F3. Note the millimetre scale pyrite nodules. E) Close-up view of FA9 dominated by F3 with a carbonate cemented Planolites burrow. $\mathrm{Ch}=$ Chondrites, $\mathrm{He}=$ Helminthopsis, $\mathrm{Ph}=$ Phycosiphon, $\mathrm{Pl}=$ Planolites. 


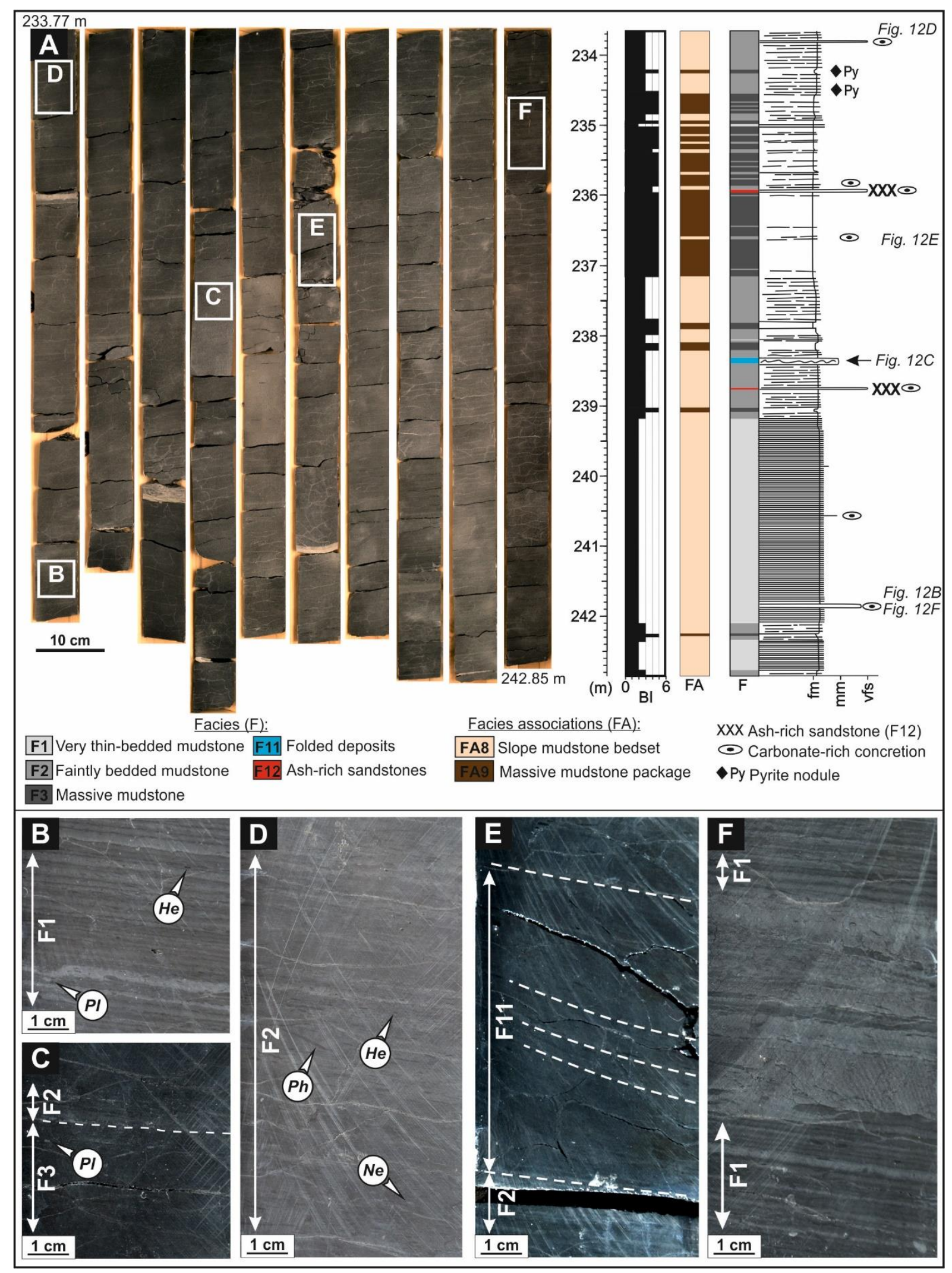


Figure 12: A) Representative $9.08 \mathrm{~m}$-thick core section and sedimentological log from the lower slope B/C mudstone unit (see Figure 10 for stratigraphic position). F1 and F2 stack to form slope mudstone bedsets (FA8) up to $8 \mathrm{~m}$-thick, intercalated with packages dominated by F3 to form massive mudstone packages (FA9). Bioturbation index scale from Taylor and Goldring (1993). B) Close up view of FA8 dominated by F1 beds, which usually more bioturbated in the slope mudstones than in the basin-floor mudstones. C) Close-up view of an isolated very thin bed of F2 within FA9. D) Close-up view of FA8 dominated by F2. E) Close-up view of FA8 with folded deposits (F11) characterised by discordant beds. F) Close-up view of a carbonate-rich concretion within FA9 dominated by F1. He = Helminthopsis, Ne $=$ Nereites,$P h=$ Phycosiphon, $P l=$ Planolites . 


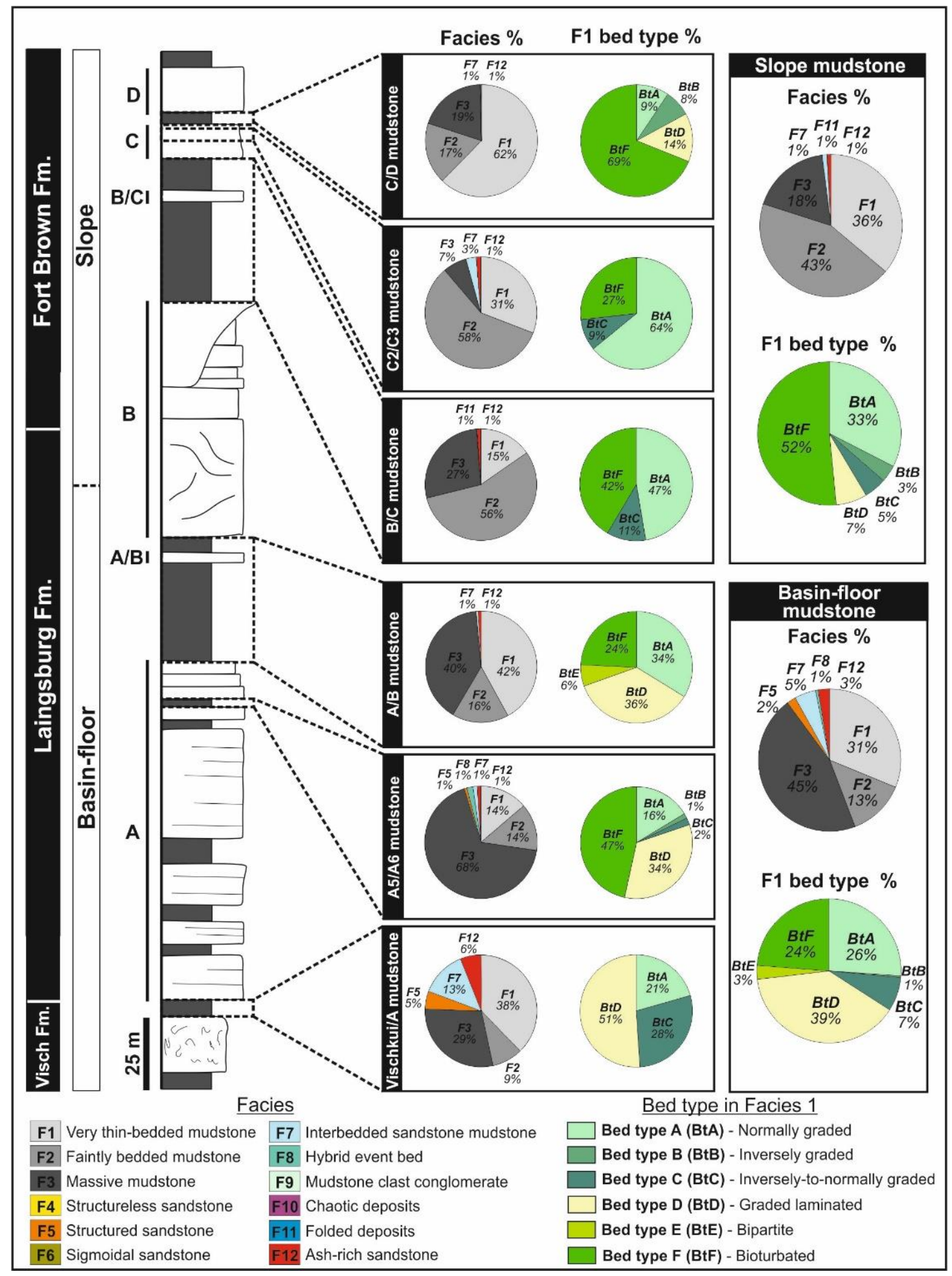

Figure 13: Stratigraphic distribution of facies and the six different types of bed identified in Facies 1 per mudstone unit (relative proportion by thickness). 

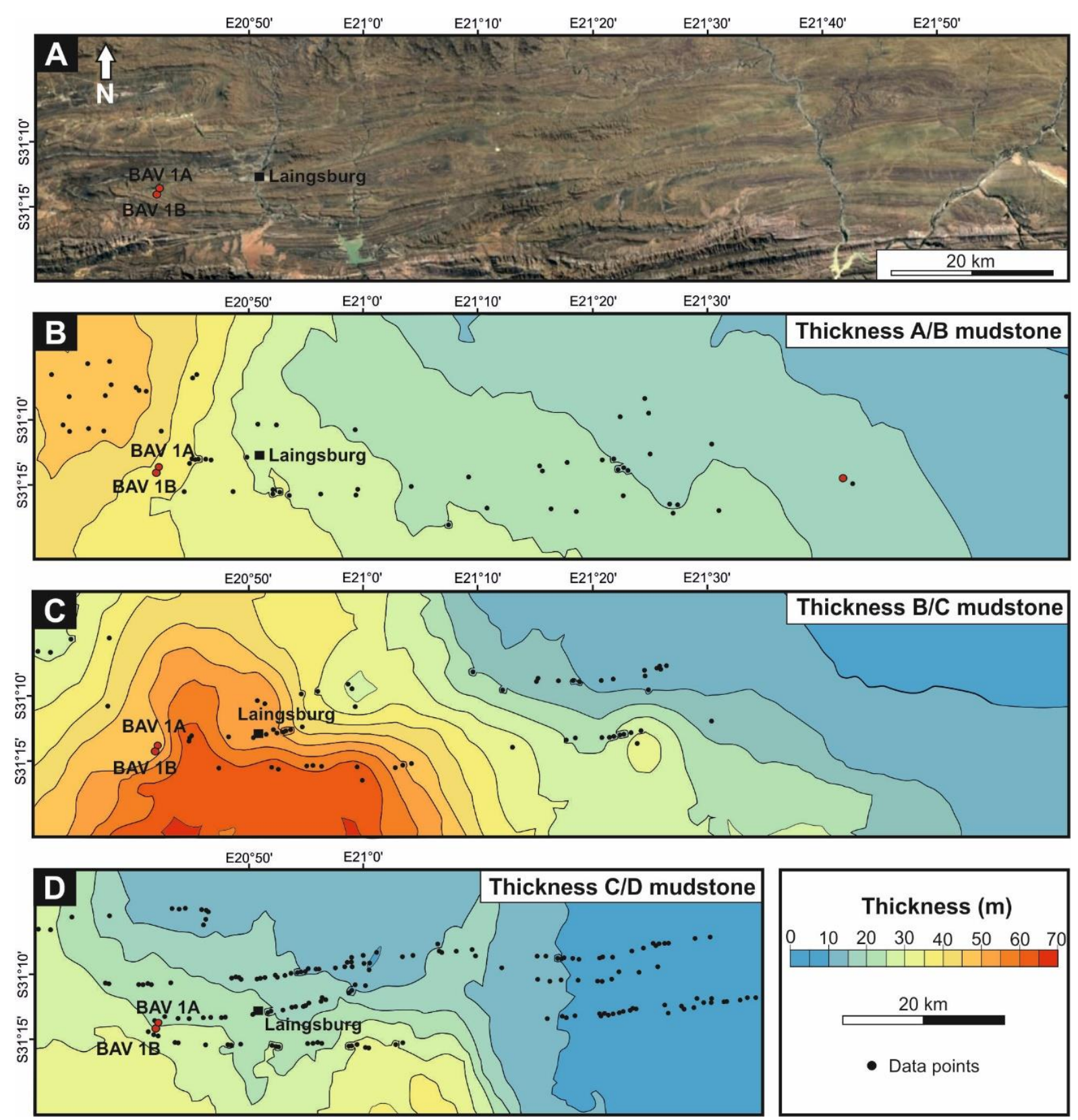

Figure 14: A) Satellite view of the Laingsburg depocentre with drilling location of the two cores described in this study. B) Thickness map of the A/B mudstone unit. C) Thickness map of the B/C mudstone unit. D) Thickness map of the C/D mudstone unit. Note the overall gradual basinward thinning to the northeast and the resulting wedge shape geometry of each mudstone unit. 


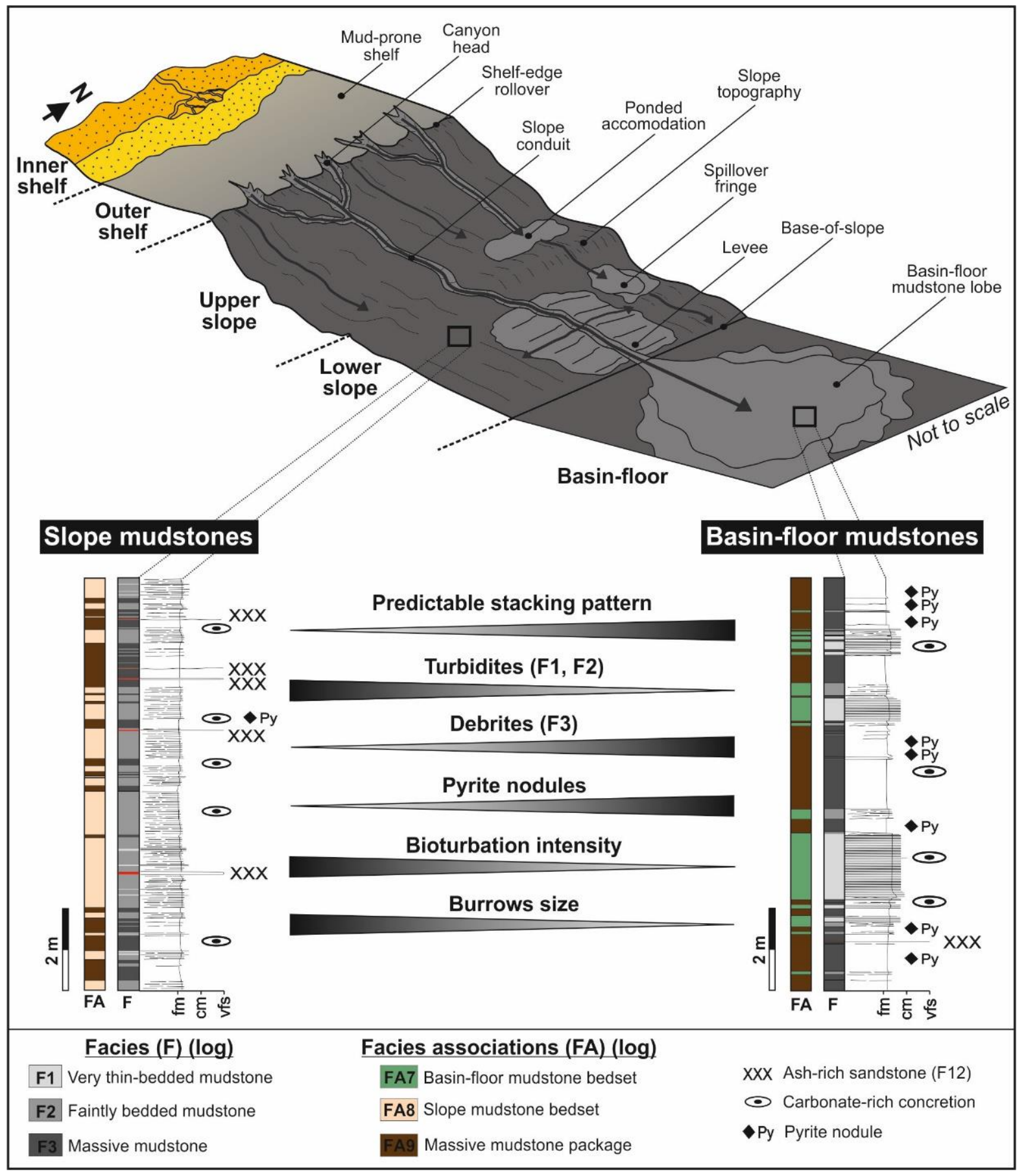

Figure 15: Reconstruction of shelf, slope, and basin-floor depositional environments during accumulation of the regional deep-water mudstone units of the Laingsburg and Fort Brown formations. Representative core sections for slope (BAV1A; 215 to $210 \mathrm{~m}$ ) and basin-floor mudstones (BAV1B; 202.5 to $192.5 \mathrm{~m}$ ) are represented. Each mudstone unit has been mapped for $>50 \mathrm{~km}$ down depositional dip and for $>25 \mathrm{~km}$ across strike to confirm almost no sand deposited in the slope and basin floor at these times. The coeval high-accommodation shelf was mud-prone, and sediment gravity flows delivered mud to the slope and basin-floor by a combination of a) line-sourced delivery beyond the shelf edge, and b) point-sourced delivery through local slope canyon-channel systems, which were not completely filled and still active during backstepping of the sand-rich delivery systems. 


\section{TABLES}

Table 1: Sandstone-prone facies description (F4-F12), process interpretation, and representative core photographs. Bioturbation index (BI) from Taylor and Goldring (1993).

\begin{tabular}{|c|c|c|c|c|c|c|}
\hline $\begin{array}{l}\text { Facies } \\
\text { Name }\end{array}$ & $\begin{array}{c}\text { Grain } \\
\text { Size }\end{array}$ & $\begin{array}{c}\text { Bed } \\
\text { Thic } \\
\text { kness } \\
\text { Rang } \\
\text { e }\end{array}$ & Description & $\begin{array}{c}\text { Biotu } \\
\text { rbati } \\
\text { on }\end{array}$ & $\begin{array}{c}\text { Depositional } \\
\text { Processes }\end{array}$ & Core Photograph \\
\hline $\begin{array}{l}\text { Structure } \\
\text { less } \\
\text { sandstone } \\
\text { (F4) }\end{array}$ & $\begin{array}{l}\text { Very } \\
\text { fine to } \\
\text { fine } \\
\text { sand }\end{array}$ & $\begin{array}{l}10- \\
200 \\
\mathrm{~cm}\end{array}$ & $\begin{array}{l}\text { Structureless. } \\
\text { Occasional dewatering } \\
\text { pipes and dishes. Sharp, } \\
\text { erosional or loaded } \\
\text { bases. Common flute } \\
\text { and tool marks. Sharp } \\
\text { tops. }\end{array}$ & BI: 0 & $\begin{array}{l}\text { High-density turbidites: } \\
\text { Massive structuration } \\
\text { suggests deposition from } \\
\text { highly concentrated flow } \\
\text { (Lowe, 1982; Kneller and } \\
\text { Branney, 1995) with high } \\
\text { sediment load fallout } \\
\text { (Arnott and Hand, 1989). }\end{array}$ & 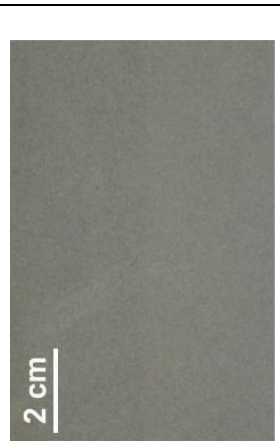 \\
\hline $\begin{array}{l}\text { Structure } \\
\text { d } \\
\text { sandstone } \\
\text { (F5) }\end{array}$ & $\begin{array}{l}\text { Very } \\
\text { fine to } \\
\text { fine } \\
\text { sand }\end{array}$ & $\begin{array}{l}5-70 \\
\mathrm{~cm}\end{array}$ & $\begin{array}{l}\text { Planar, current-ripple or } \\
\text { low-angle climbing- } \\
\text { ripple lamination. Sharp } \\
\text { or loaded bases. Sharp } \\
\text { or gradational tops, } \\
\text { commonly undulating. } \\
\text { Mudstone drapes. }\end{array}$ & $\begin{array}{l}\text { BI: } 0- \\
2\end{array}$ & $\begin{array}{l}\text { Low-density turbidites: } \\
\text { Planar and current-ripple } \\
\text { lamination produced by } \\
\text { tractional reworking of } \\
\text { bed tops by dilute flows } \\
\text { (Allen, 1982; Best and } \\
\text { Bridge, 1992). Climbing- } \\
\text { ripple lamination forms } \\
\text { under bedload transport } \\
\text { associated with high } \\
\text { aggradation rates (Hunter, } \\
\text { 1977; Jobe et al., 2012). }\end{array}$ & $\begin{array}{l}\text { E్ } \\
\text { N }\end{array}$ \\
\hline $\begin{array}{l}\text { Sigmoidal } \\
\text { sandstone } \\
\text { (F6) }\end{array}$ & $\begin{array}{l}\text { Very } \\
\text { fine } \\
\text { sand }\end{array}$ & $\begin{array}{l}2-30 \\
\mathrm{~cm}\end{array}$ & $\begin{array}{l}\text { Sigmoidal shaped } \\
\text { bedform with sinusoidal } \\
\text { lamination. Stoss-side } \\
\text { preserved climbing } \\
\text { ripple lamination. } \\
\text { Current-ripple, planar or } \\
\text { low-angle ripple } \\
\text { lamination. Sharp bases. } \\
\text { Gradational tops. }\end{array}$ & $\begin{array}{l}\text { BI: } 0- \\
2\end{array}$ & $\begin{array}{l}\text { Low-density turbidites: } \\
\text { Sinusoidal and climbing- } \\
\text { ripple lamination } \\
\text { associated with high rates } \\
\text { of deposition (Hunter, } \\
\text { 1977; Jobe et al., 2012). } \\
\text { Deposited from flows } \\
\text { escaping confinement and } \\
\text { depositing rapidly (Morris } \\
\text { et al., 2014b). }\end{array}$ & 형 \\
\hline
\end{tabular}




\begin{tabular}{|c|c|c|c|c|c|c|}
\hline $\begin{array}{l}\text { Interbedd } \\
\text { ed } \\
\text { sandstone } \\
\text { and } \\
\text { mudstone } \\
\text { (F7) }\end{array}$ & $\begin{array}{l}\text { Coarse } \\
\text { mud to } \\
\text { very } \\
\text { fine } \\
\text { sand }\end{array}$ & $\begin{array}{l}1-15 \\
\mathrm{~cm}\end{array}$ & $\begin{array}{l}\text { Very fine sandstones } \\
\text { include wavy, } \\
\text { aggradational, planar, } \\
\text { current-ripple, climbing, } \\
\text { and stoss-side preserved } \\
\text { climbing ripple } \\
\text { lamination. Mudstone } \\
\text { drapes with planar } \\
\text { laminations. } \\
\text { Gradational or sharp } \\
\text { bases. Often gradational } \\
\text { tops. }\end{array}$ & $\begin{array}{l}\text { BI: } 0- \\
3\end{array}$ & $\begin{array}{l}\text { Low-density turbidites: } \\
\text { Planar and current-ripple } \\
\text { lamination produced by } \\
\text { tractional reworking of } \\
\text { bed tops by dilute flows } \\
\text { (Allen, 1982; Best and } \\
\text { Bridge, 1992). Climbing- } \\
\text { ripple lamination forms } \\
\text { under bedload transport } \\
\text { associated with high } \\
\text { aggradation rates (Hunter, } \\
\text { 1977; Jobe et al., 2012). } \\
\text { Wavy lamination } \\
\text { associated with waning } \\
\text { flows and high rates of } \\
\text { suspension fallout } \\
\text { (Jopling and Walker, } \\
\text { 1968; Hunter, 1977). Mud } \\
\text { deposited by the dilute tail } \\
\text { of the flow. }\end{array}$ & 텽 \\
\hline $\begin{array}{l}\text { Hybrid } \\
\text { event bed } \\
\text { (F8) }\end{array}$ & $\begin{array}{l}\text { Fine } \\
\text { mud to } \\
\text { very } \\
\text { fine } \\
\text { sand }\end{array}$ & $\begin{array}{l}20- \\
150 \\
\mathrm{~cm}\end{array}$ & $\begin{array}{l}\text { Two subdivisions. } \\
\text { Lower subdivision (A) } \\
\text { well sorted and "clean" } \\
\text { sandstone. Upper } \\
\text { subdivision (B) can be: } \\
\text { (1) mudstone-clast rich } \\
\text { with "clean" matrix; (2) } \\
\text { argillaceous, poorly } \\
\text { sorted sandstone with } \\
\text { swirly and patchy fabric } \\
\text { comprising mudstone } \\
\text { chips and wood } \\
\text { fragments. Sharp or } \\
\text { erosional bases. Sharp } \\
\text { tops. }\end{array}$ & $\begin{array}{l}\text { BI: 0- } \\
3\end{array}$ & $\begin{array}{l}\text { Hybrid event beds: } \\
\text { Strongly stratified } \\
\text { transitional flows (Baas et } \\
\text { al. 2011; Kane and } \\
\text { Pontén, 2012) or co- } \\
\text { genetic turbidity currents } \\
\text { (lower subdivision) and } \\
\text { cohesive debris flows } \\
\text { (upper subdivision) } \\
\text { (Haughton et al., 2003). }\end{array}$ & हี \\
\hline $\begin{array}{l}\text { Mudstone } \\
\text { clast } \\
\text { conglome } \\
\text { rate (F9) }\end{array}$ & $\begin{array}{l}\text { Fine } \\
\text { sand }\end{array}$ & $\begin{array}{l}1-10 \\
\mathrm{~cm}\end{array}$ & $\begin{array}{l}\text { Tightly packed } \\
\text { mudstone clasts draping } \\
\text { erosive surfaces. From } \\
\text { high concentration clast } \\
\text { supported to matrix } \\
\text { supported } \\
\text { conglomerate. Sharp } \\
\text { and erosional bases, } \\
\text { normally planar with } \\
\text { local topography related } \\
\text { to the substrate } \\
\text { erodibility. }\end{array}$ & BI: 0 & $\begin{array}{l}\text { Channel lags/drapes: } \\
\text { Mudclasts transported in } \\
\text { traction beneath confined } \\
\text { flows and deposited as } \\
\text { channel lag/drape. }\end{array}$ & $\begin{array}{l}\text { E⿱ } \\
\text { N }\end{array}$ \\
\hline
\end{tabular}




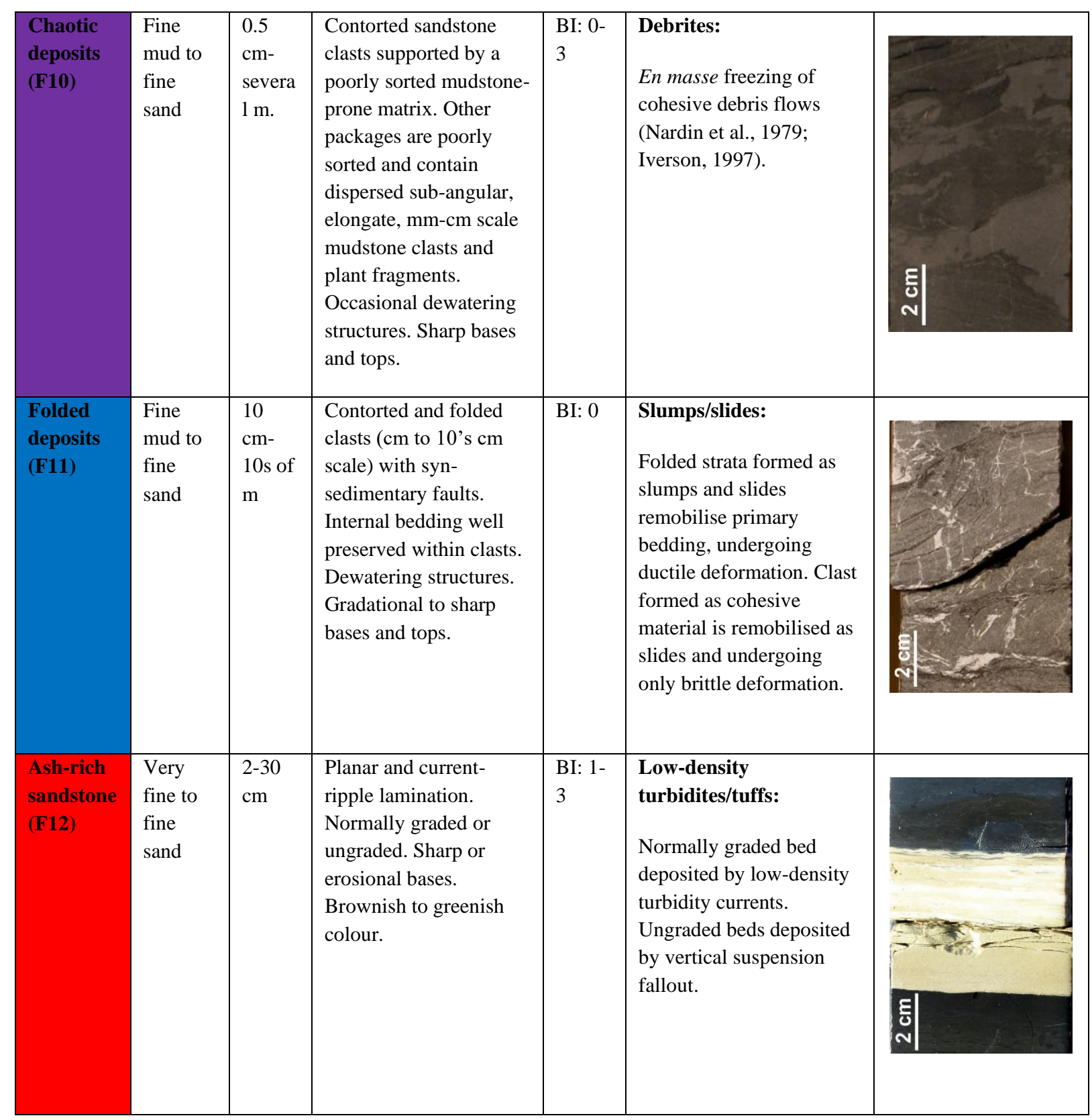


Table 2: Facies associations (FA1-FA9) descriptions.

\begin{tabular}{|c|c|c|c|c|}
\hline & $\begin{array}{l}\text { FA } \\
\text { code }\end{array}$ & $\begin{array}{l}\text { Facies } \\
\text { Association } \\
\text { Name }\end{array}$ & Common Facies & Main Characteristics \\
\hline \multirow{6}{*}{ 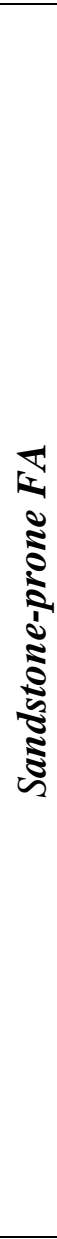 } & FA1 & $\begin{array}{l}\text { Proximal lobe } \\
\text { (axis to } \\
\text { fringe) }\end{array}$ & $\begin{array}{l}\text { Structureless sandstone }(\mathbf{F 4}), \\
\text { structured sandstone }(\mathbf{F 5}), \\
\text { sigmoidal sandstone }(\mathbf{F 6}), \\
\text { interbedded sandstone and } \\
\text { mudstone }(\mathbf{F 7}), \text { bipartite bed } \\
(\mathbf{F 8}), \text { mudstone clast } \\
\text { conglomerate }(\mathbf{F 9}) \text {, chaotic } \\
\text { deposits }(\mathbf{F 1 0})\end{array}$ & $\begin{array}{l}10 \text { 's of } \mathrm{cm} \text { to a few m-thick. Tabular-shape deposits. } \\
\text { Decrease of sand content from axis to fringe. Axis: } \\
\text { directly down-dip of the feeder channel, common } \\
\text { erosion, bypass and bed amalgamation. Off-axis: } \\
\text { Alternation of bedded sandstones and mudstones. } \\
\text { Fringe: Lower sand content; alternation of bedded } \\
\text { sandstones and mudstones with common hybrid } \\
\text { event beds (F8) in frontal position. }\end{array}$ \\
\hline & FA2 & $\begin{array}{l}\text { Distal lobe } \\
\text { (distal fringe) }\end{array}$ & $\begin{array}{l}\text { Very thin-bedded mudstone }(\mathbf{F 1}), \\
\text { faintly bedded mudstone }(\mathbf{F 2}), \\
\text { interbedded sandstone and } \\
\text { mudstone (F7), ash-rich } \\
\text { sandstone (F12) }\end{array}$ & $\begin{array}{l}\text { Few cm to a few m-thick. Tabular-shape deposits } \\
\text { that correlate laterally to proximal lobe deposits. } \\
\text { Very thin-bedded mudstone (F1) deposited in more } \\
\text { proximal environment compared to faintly bedded } \\
\text { mudstone (F2). }\end{array}$ \\
\hline & FA3 & Channel fill & $\begin{array}{l}\text { Structureless sandstone }(\mathbf{F 4}), \\
\text { structured sandstone }(\mathbf{F 5}), \\
\text { interbedded sandstone and } \\
\text { mudstone }(\mathbf{F 7}), \text { mudstone clast } \\
\text { conglomerate }(\mathbf{F 9}), \text { folded } \\
\text { deposits }(\mathbf{F 1 1})\end{array}$ & $\begin{array}{l}\text { Few m-thick. Lens shape deposits filling concave-up } \\
\text { surfaces. Axial zones with repeated phases of } \\
\text { erosion/deposition and common amalgamation and } \\
\text { bypass surfaces. Gradual thinning and fining away } \\
\text { from axial zone, with low angle erosional surfaces } \\
\text { identified through bed truncation. }\end{array}$ \\
\hline & FA4 & Levee & $\begin{array}{l}\text { Sigmoidal sandstone }(\mathbf{F 6}) \\
\text { interbedded sandstone and } \\
\text { mudstone }(\mathbf{F 7})\end{array}$ & $\begin{array}{l}\text { Few m to } 10 \text { 's of m-thick. Wedge-shape geometry } \\
\text { away from channel over } 100 \text { 's of m. Fining and } \\
\text { thinning-upward rhythmic alternations. Deposits } \\
\text { closer to coeval channel exhibit highly tractional and } \\
\text { rapidly deposited structures, often recording multi- } \\
\text { directional current ripple and climbing ripple } \\
\text { lamination. Sandstone content decreases non-linearly } \\
\text { away from the channel. }\end{array}$ \\
\hline & FA5 & $\begin{array}{l}\text { Intraslope } \\
\text { frontal lobe }\end{array}$ & $\begin{array}{l}\text { Structured sandstone }(\mathbf{F 5}), \\
\text { sigmoidal sandstone }(\mathbf{F 6}), \\
\text { interbedded sandstone and } \\
\text { mudstone }(\mathbf{F 7}), \text { bipartite bed }(\mathbf{F 8})\end{array}$ & $\begin{array}{l}\text { Few m-thick. Mounded geometry. High rates of } \\
\text { suspension fallout linked to rapid flow expansion } \\
\text { and deposition directly down-dip of slope channels. }\end{array}$ \\
\hline & FA6 & Remobilised & $\begin{array}{l}\text { Chaotic deposits }(\text { F10), folded } \\
\text { deposits (F11) }\end{array}$ & $\begin{array}{l}\text { Few m-thick. Chaotic and remobilised deposits } \\
\text { filling slide scars and topography created by mass- } \\
\text { transport deposits. }\end{array}$ \\
\hline \multirow{3}{*}{ 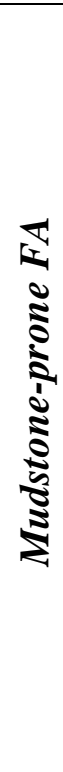 } & FA7 & $\begin{array}{l}\text { Basin-floor } \\
\text { mudstone } \\
\text { bedset }\end{array}$ & $\begin{array}{l}\text { Very thin-bedded mudstone }(\mathbf{F 1}), \\
\text { faintly bedded mudstone }(\mathbf{F 2}), \\
\text { interbedded sandstone and } \\
\text { mudstone }(\mathbf{F} 7), \text { ash-rich } \\
\text { sandstone (F12) }\end{array}$ & $\begin{array}{l}\text { Few cm to a few m-thick (up to } 1.7 \mathrm{~m} \text { thick). Do not } \\
\text { correlate laterally to any sandstones on the basin- } \\
\text { floor. Most dominant bed type of } \mathrm{F} 1 \text { is graded } \\
\text { laminated (Bed type D), followed by normally } \\
\text { graded (Bed type A), bioturbated (Bed type F), } \\
\text { inversely-to-normally graded (Bed type C), bipartite } \\
\text { (Bed type E) and inversely graded (Bed type B). Rare } \\
\text { ash-rich sandstones (F12) and carbonate-rich } \\
\text { concretions. }\end{array}$ \\
\hline & FA8 & $\begin{array}{l}\text { Slope } \\
\text { mudstone } \\
\text { bedset }\end{array}$ & $\begin{array}{l}\text { Very thin-bedded mudstone (F1), } \\
\text { faintly bedded mudstone (F2), } \\
\text { ash-rich sandstone (F12) }\end{array}$ & $\begin{array}{l}\text { Few cm to few m-thick (up to } 8 \mathrm{~m} \text { thick). Do not } \\
\text { correlate laterally to any sandstones on the slope. } \\
\text { Most dominated bed type of F1 is bioturbated (Bed } \\
\text { type F), followed by normally graded (Bed type A), } \\
\text { graded laminated (Bed type } D \text { ), inversely-to- } \\
\text { normally graded (Bed type } C \text { ), and inversely graded } \\
(\text { Bed type } B \text { ). Common ash-rich sandstones (F12) } \\
\text { and carbonate-rich concretions. Higher bioturbation } \\
\text { intensity and larger burrows compared to FA7. }\end{array}$ \\
\hline & FA9 & $\begin{array}{l}\text { Massive } \\
\text { mudstone } \\
\text { package }\end{array}$ & $\begin{array}{l}\text { Massive mudstone (F3), ash-rich } \\
\text { sandstone (F12) }\end{array}$ & $\begin{array}{l}\text { Few } \mathrm{cm} \text { to few m-thick. Packages of massive } \\
\text { mudstones are thicker in the basin-floor compared to } \\
\text { the slope. Common pyrite nodules in the basin-floor. }\end{array}$ \\
\hline
\end{tabular}

